\title{
KAJIAN YURIDIS TERHADAP PERAN MAHKAMAH KONSTITUSI SEBAGAI POSITIF LEGISLATOR ATAS PUTUSAN NO. 21/PUU-XII/2014 TENTANG PENAMBAHAN OBJEK PENETAPAN STATUS TERSANGKA DALAM PRAPERADILAN
}

\author{
Agus Prabowo dan Agus Manfaluthfi \\ Fakultas Hukum Universitas Islam Kediri
}

\begin{abstract}
One of the Authorities of the Constitutional Court is to review the Act against the 1945 Constitution or commonly referred to as the judicial review of the Constitutional Court in passing the Tests Act against the 1945 Constitution is only allowed to interpret the contents of the Act in accordance with the original intent made by the institution authorized to establish its (Positive Legislator). The Constitutional Court may only declare a Constitution contrary to the 1945 Constitution and is not permitted to enter the legislative domain (participate in any arrangement) in its general limitation. Such Tasks and Authorities are attributed to the notion that the House of Representatives and the Government are Positive Legislator (the author of the norm) while the Constitutional Court is a Negative Legislator (eraser or nullifying norm). This is reinforced by Article 57 of Law No. 8 of 2011 on the Constitutional Court. But in the Constitutional Court Decision Number 21 / PUU-XII / 2014 About the addition of suspect status assignment into Pretrial Objects. Constitutional Court Justices have provided interpretation by adding new norms to the tested norms. This has given many legal consequences and new law problems in society. Because the Constitutional Court's decision is Final and binding since it was first pronounced in open plenary session. Without any legal action that can be taken related to the content of the decision.
\end{abstract}

Keywords: Constitutional Court, Judicial Review, Pretrial, and Judge's Decision.

ABSTRAK
Salah satu Kewenangan Mahkamah Konstitusi Adalah melakukan pengujian Undang-Undang terhadap Undang-Undang Dasar 1945 atau yang biasa di sebut dengan judicial review Mahkamah Konstitusi dalam melalukan Pengujian Undang-Undang terhadap Undang-Undang Dasar 1945 hanya di perbolehkan menafsirkan isi Undang-Undang sesuai dengan original intent yang dibuat oleh lembaga yang berwenang menetapkan nya(Positif Legislator). Mahkamah Konstitusi hanya boleh menyatakan sebuah Undang-Undang bertentangan Dengan Undang-Undang Dasar 1945 dan tidak diperbolehkan memasuki ranah legislatif(ikut mengatur)dengan cara apapun.pada umum nya pembatasan Tugas dan Wewenang yang demikian dikaitkan dengan pengertian bahwa Dewan Perwakilan Rakyat dan Pemerintah adalah Positif Legislator(pembuat norma) sedangkan Mahkamah Konstitusi merupakan lembaga Negatif Legislator(penghapus atau pembatal norma).hal ini di perkuat dengan Pasal 57 Undang-Undang Nomor 8 tahun 2011 tentang Mahkamah Konstitusi. Namun dalam Putusan Mahkamah Konstitusi Nomor 21/PUU-XII/2014 Tentang penambahan penetapan status tersangka kedalam Objek Praperadilan. Hakim Mahkamah konstitusi telah memberikan penafsiran dengan menambahkan norma baru terhadap norma yang di ujikan. Hal ini banyak memberikan akibat Hukum serta permasalah Hukum baru dalam masyarakat. Karena ketetapan Mahkamah Konstitusi Bersifat Final dan mengikat sejak pertama kali di ucapkan dalam sidang pleno terbuka. Tanpa adanya upaya hukum lagi yang bisa di ambil terkait isi putusan tersebut.

Kata Kunci : Mahkamah Konstitusi, Judicial Review, Praperadilan, dan Putusan Hakim. 


\section{Pendahuluan}

Dunia hukum setidaknya dikenal dengan empat macam sistem hukum yang banyak di anut oleh berbagai negara di dunia yaitu sistem hukum Eropa konstinental, anglo saxon sistem hukum adat dan hukum agama. Sistem hukum sistem hukum Eropa konstinental biasanya di sebut civil law karena bersumber pada kodifikasi hukum. Prinsip dasarnya ialah bahwa hukum itu memperoleh kekuasaan mengikat karena berupa peraturan yang berbentuk Undang-Undang yang tersusun secara sistematis dalam kodifikasi, sedangkan sistem hukum anglo saxon dikenal dengan istilah common law atau hukum tidak tertulis. Sistem anglo saxon merupakan suatu sistem yang di dasarkan pada yurisprudensi atau keputusan hakim terdahulu. ${ }^{1}$

Sistem hukum adat adalah seperangkat norma dan aturan adat atau kebiasaan yang berlaku di suatu wilayah. Sistem ini memiliki sanksi sesuai dengan aturan hukum yang berlaku di wilayah tertentu. Sistem hukum agama adalah sistem hukum yang berdasarkan pada ketentuan agama tertentu. Sistem hukum agama biasanya terdapat dalam kitab suci. Indonesia adalah negara yang menganut sistem hukum campuran dengan sistem hukum utama yaitu sistem hukum Eropa konstinental. Selain Eropa kontinental di Indonesia juga berlaku hukum adat dan sistem hukum agama khususnya Syariah.

Menurut isinya hukum dapat dibagi dalam hukum privat (sipil) dan hukum publik (hukum negara). Hukum privat dibagi menjadi 2 yaitu hukum yang mengatur hubungan-hubungan antara orang yang satu dengan orang yang lain, dengan menitik beratkan kepada kepentingan perseorangan. Hukum sipil terdiri dari hukum perdata dan hukum dagang. ${ }^{2}$ Sedangkan yang dimaksud hukum publik yaitu hukum yang mengatur hubungan antara negara dengan alat-alat

\footnotetext{
${ }^{1}$ Khayatudin, Pengantar Mengenal Hukum Indonesia, Kediri: Uniska Prees, 2010, hlm 26.

${ }^{2}$ Cst Kansil,. Pengantar Ilmu Hukum Dan Tata Hukum Indonesia. Cetakan Ke-7, Jakarta : Balai Pustaka, 1986, hlm 76.
} 
perlengkapan negara atau hubungan antara negara dengan perseorangan (warga negara).

Adapun cabang dari hukum publik antara lain Hukum Tata Negara dan Administrasi Negara. Hukum Tata Negara yaitu hukum yang mengatur bentuk dan susunan pemerintahan suatu Negara serta hubungan antara alat-alat perlengkapan satu sama lain dan hubungan antara Negara (Pemerintah pusat) dengan bagian-bagian Negara. Hukum Administrasi Negara yaitu hukum yang mengatur cara-cara menjalankan tugas (hak dan kewajiban) dari kekuasaan alatalat perlengkapan Negara. ${ }^{3}$

Undang-Undang Dasar Negara Republik Indonesia Tahun 1945 menegaskan bahwa kedaulatan berada ditangan rakyat dan dilaksanakan menurut Undang-Undang Dasar. Kemudian ditegaskan pula bahwa Negara Indonesia adalah Negara Hukum. Sejalan dengan ketentuan itu maka salah satu prinsip penting Negara Hukum adalah adanya jaminan penyelenggaraan kekuasaan kehakiman yang merdeka bebas dari pengaruh kekuasaan lainnya untuk menyelengarakan peradilan guna menegakan hukum dan keadilan .

Kekuasaan kehakiman yang merdeka menurut Undang-Undang Dasar 1945 dilakukan oleh sebuah Mahkamah Agung dan badan Peradilan yang berada dibawahnya dalam lingkungan Peradilan Umum, Peradilan Agama, Peradilan Militer, Peradilan Tata Usaha Negara, dan oleh sebuah Mahkamah Konstitusi. Untuk menyelenggarakan Peradilan guna menegakan hukum dan keadilan.

Sejalan dengan prinsip ketatanegaraan tersebut maka salah satu substansi penting perubahan Undang-Undang Dasar 1945, dengan keberadaan Mahkamah Konstitusi sebagai lembaga Negara yang menangani perkara tertentu dibidang ketatanegaraan. Dalam rangka menjaga Konstitusi secara bertangung jawab sesuai kehendak rakyat dan cita-cita demokrasi. ${ }^{4}$

\footnotetext{
${ }^{3}$ Ibid, hlm. 76.

${ }^{4}$ Pasal 1 ayat (2) dan ayat (3) Undang-Undang Dasar Negara Republik Indonesia Tahun 1945,
} 
Keberadaan Mahkamah Konstitusi sekaligus untuk menjaga terselengaranya Pemerintahan Negara yang stabil dan juga merupakan koreksi terhadap pengalaman kehidupan ketatanegaraan dimasa lalu yang ditimbulkan oleh tafsir ganda terhadap konstitusi. Di Indonesia menganut sistem Trias politika yaitu teori yang membagi kekuasaan Pemerintahan Negara menjadi tiga jenis Kekuasaan. Pemerintah dalam hal ini menjadi eksekutif selaku pelaksana pemerintahan dan pelaksana Undang-Undang (executife powers).

Sedangan fungsi legislatif merupakan kewenangan dari DPR (Dewan Perwakilan Rakyat) dimana Dewan Perwakilan Rakyat sebagai badan pembuat Undang-Undang (legislatif powers). Serta kekuasaan untuk mengawasi dan mengadili merupakan kewenangan yudikatif (jidicative powers). Salah satu lembaga negara yang berada dalam ranah yudikatif yaitu Mahkamah Konstitusi.

Mahkamah Konstitusi di bentuk pada bulan Agustus 2003 sebagai lembaga yang berwenang untuk menguji Undang-Undang. Pengujian konstitusional itu dalam sistem ketatanegaraan berdasarkan Undang-Undang Dasar Republik Indonesia Tahun 1945 setelah perubahan ke empat.

Pengujian konstitusional itu dimaksudkan untuk memastikan bahwa Undang-Undang Dasar 1945. Sungguh-sungguh dijalankan atau ditegakan dalam proses penyelengaraan negara pengujian terhadap lembaga lain oleh lembaga yang berbeda merupakan mekanisme baru dalam sistem hukum dan Konstitusi di Indonesia.

Di awali setelah era reformasi yaitu dengan di keluarkannya TAP MPR-RI No.III/MPR/2000 . dengan dikeluarkan nya ketetapakan MPR ini di kenal dengan legistlative reviev karena organ MPR ini merupakan salah satu kekuasaan judisial. ${ }^{5}$ Pengujian konstitusional dalam arti 'judicial review on the constitusionality of law" atau pengujian judisial atas Konstitusionalitas Undang-

${ }^{5}$ Sekretariat Jenderal MPR RI,2011, Panduan Permasyarakatan Undang-undang Dasar Negara Republik Indonesia tahun 1945 dan ketetapan Majelis Permusyarakatan Rakyat Republik Indonesia, Jakarta,hlm.153. 
Undang baru di adopsikan mekanismenya ke dalam sistem Ketatanegaraan Indonesia dengan diterima nya ide pembentukan Mahkamah Konstitusi dalam Undang-Undang Dasar Negara Republik Indonesia tahun 1945.

Tidak seperti Negara-Negara dengan tradisi "common law" seperti Amerika serikat, Indonesia dengan "civil law" mengikuti pola Eropa Konstinental dalam mengembangkan kelembagaan Mahkamah Konstitusi yang berdiri sendiri diluar dan sederajat dengan Mahkamah Agung.

Ketentuan umum mengenai Mahkamah Konstitusi ada di dalam UndangUndang Dasar 1945 di cantumkan dalam Pasal 7 B ayat (1), (3),(4), (5) dan (6) sebagai hasil perubahan ketiga Undang-Undang Dasar 1945 Pada tahun 2001. Kemudian di tambah Pasal III aturan peralihan Undang-Undang Dasar 1945 hasil perubahan keempat Undang-Undang Dasar 1945 pada tahun 2002.

Undang-Undang yang mengatur lebih lanjut tentang Mahkamah Konstitusi tertuang pada Undang-Undang Nomor 24 Tahun 2003 tentang Mahkamah Konstitusi untuk kemudian di revisi lagi menjadi Undang-Undang Nomor 08 Tahun 2011.

Mahkamah Konstitusi dalam menguji Undang-Undang terhadap UndangUndang Dasar 1945 berfungsi sebagai pembatal norma atau negatif legislator dan di larang membuat rumusan norma baru atas norma yang sudah di batalkan atau membuat putusan yang bersifat positive legislator hal ini sesuai dengan amanat Pasal 57 Undang-Undang Nomor 08 Tahun 2011 tentang Mahkamah Konstitusi, namun dalam putusan Mahkamah Konstitusi Nomor 21/PUU-XII-2014 atas perkara pengujian Pasal 77 huruf (a) KUHAP terkait dengan fungsi Mahkamah Konstitusi sebagai positive legislator dalam putusan tersebut adalah kurang tepat.

Mahkamah Konstitusi negative legislator hal ini berkebalikan dengan fungsi Dewan Perwakilan Rakyat dan Presiden sebagai pembuat Undang-Undang 
(positive legislator). ${ }^{6}$ Mahkamah Konstitusi Sebagai negative legislator dalam amar putusannya tidak boleh memuat kententuan yang bersifat mengatur sebagai mana di atur dalam Pasal 57 ayat 2 (a) Undang-Undang Mahkamah Konstitusi yang berbunyi sebagai berikut:

Pasal 57 ayat (2) Putusan Mahkamah Konstitusi tidak memuat:

1.1. Amar selain sebagaimana di maksud dalam ayat (1) dan (2).

1.2. Perintah terhadap pembuat Undang-Undang dan

1.3. Rumusan norma baru sebagai penganti norma dari Undang-Undang yang di nyatakan bertentangan dengan Undang-Undang Dasar 1945.

Ketentuan Pasal 57 ayat (2a) Undang-Undang Mahkamah Konstitusi diatas dimaksud agar Mahkamah Konstitusi sebagai negative legislator tidak mencampuri kewenangan Dewan Perwakilan Rakyat Sebagai positive legistalor. Yaitu dengan memuat norma baru terhadap norma yang sudah di batalkan.

Putusan Mahkamah Konstitusi yang memuat norma baru dalam norma yang di batalkan di antaranya adalah Putusan Mahkamah Konstitusi Nomor 21/PUUXII/2014 Tentang pengujian terhadap Undang-Undang Nomor 8 tahun 1981 tentang Hukum acara pidana (KUHAP).

Salah satu pasal yang dimohonkan pengujiannya adalah pengujian Pasal 77 huruf a KUHAP perihal objek Praperadilan yang berbunyi " Pengadilan Negeri berwenang untuk memeriksa dan memutus sesuai dengan ketentuan yang di atur dalam Undang-Undang ini tentang sah atau tidak nya suatu penangkapan, penahanan dan penghentian penyidikan atau penghentian penuntutan.

Amar putusan Mahkamah Konstitusi dalam mengadili permohonan tersebut adalah sebagai berikut Pasal 77 huruf a Undang-Undang Nomor 08 tahun 1981 tentang KUHAP bertentangan dengan Undang-Undang Dasar 1945 sepanjang tidak dimaknai termasuk penetapan tersangka, penggeledahan dan penyitaan.

\footnotetext{
${ }^{6}$ Jimly Ashiddiqie, Pokok-pokok Hukum Tata Negara Indonesia Pasca Reformasi, Jakarta: PT.Bhuana Ilmu Populer, 2007, hlm. 609
} 
Amar putusan tersebut menyatakan bahwa norma yang diuji di nyatakan bertentangan dengan Konstitusi atau Inkonstitusional tetapi disertai dengan syarat pemaknaan tertentu adanya syarat tersebut dapat dimaknai bahwa secara tidak langsung Mahkamah Konstitusi telah memberikan perintah terhadap pembentuk Undang -Undang untuk memaknai atauran yang telah di buatnya agar di maknai sebagaimana pemaknaan yang telah diberikan oleh Hakim Konstitusi. Hal itu jelas bertentangan dengan Pasal 57 huruf (2a) Undang-Undang Nomor 08 tahun 2011 tentang Mahkamah Konstitusi.

Pemaknaan tersebut jika dikaitkan dengan pasal 47 Undang-Undang Nomor 08 tahun 2011 tentang Mahkamah Konstitusi yang menyatakan bahwa keputusan Mahkamah Konstitusi memperoleh kekuatan hukum tetap sejak selesai diucapkan dalam sidang pleno terbuka untuk umum.dan sifat putusan yang mengikat untuk umum (erga omnes) serta sifat putusan final and binding. dapat diartikan bahwa mahkamah konstitusi telah membuat norma baru atau membuat putusan yang bersifat positive legislator.

Karena pemaknaan yang diberikan oleh hakim Mahkamah Konstitusi langsung memperoleh kekuatan hukum tetap dan mengikat untuk umum. Serta tidak ada upaya hukum lagi yang dapat di tempuh atas putusan tersebut. Hal ini jelas bertentangan dengan fungsi Mahkamah Konstitusi sebagai negative legislator.

Putusan tersebut membuat Mahkamah Konstitusi seakan telah mengintervensi ranah legislatif melalui penafsiran yang diberikan. Seorang Hakim memang diperkenankan untuk membuat penafsiran atau interpretasi yaitu dengan menggali, mengikuti, dan memahami nilai-nilai Hukum Dan rasa keadilan yang hidup di masyarakat. Sebagai mana di atur dalam Undang-Undang Nomor 48 tahun 2009 tentang kekuasaan kehakiman.

Hal itu dikarenakan dalam mengadili perkara yang konkrit sangat mungkin hakim tidak mendapati aturannya atau aturannya ada tetapi tidak jelas. Sehingga diperlukan sebuah interpletasi untuk menemukan hukum dari peristiwa konkrit 
yang diadili.tersebut. disisi yang lain jika dikaitkan dengan Pasal 57 ayat 1 dan 2 Undang-Undang Mahkamah Konstitusi. Penafsiran tersebut digunakan hanya sebatas untuk menyatakan sebuah norma itu konstitusional atau tidak.

Menurut martitah Hakim Mahkamah Konstitusi dalam membuat putusan yang positve legistator bersifat merupakan perwujudan dari diskresi hakim yang tidak dapat digolongkan sebagai interversi terhadap ranah legislatif. Hakim tentunya memiliki alasan dan pertimbangan tersendiri dalam melakukan diskresi, tetapi jika membiarkan diskresi tanpa batasan di kawatirkan Mahkamah Konstitusi akan over power dalam menjalakan fungsinya serta dalam hubungannya dengan lembaga legislatif berdasarkan prinsip check and balances. ${ }^{7}$

Sedangkan menurut ketua Mahkamah Konstitusi periode 2008-2014 Prof.Dr.Mahfud MD, Dalam bukunya yang berjudul konstitusi dan Hukum dalam kontroversi isu menyatakan bahwa Mahkamah Konstitusi dalam meberikan putusannya dilarang melampaui batas kewenangan nya, Mahkamah Konstitusi hanya boleh menyatakan sebuah Undang-Undang bertentangan atau tidak dengan Undang-Undang Dasar dan tidak boleh masuk ke ranah legislatif (ikut mengatur) dengan cara apapun. Pada umum nya pembatasan tugas yang demikian dikaitkan dengan pergertian bahwa Dewan Perwakilan Rakyat dan Pemerintah adalah positive legislator (pembuat norma) sedangkan Mahkamah Konstitusi adalah negative legislator (penghapus atau pembatal norma). ${ }^{8}$

Ini penting ditekan kan karena secara historis dan filosofis Undang-Undang Dasar Negara Indonesia tahun 1945 tidak memperbolehkan Mahkamah Konstitusi mengintervensi ranah legislatif dengan ikut menjadi positive legislator .(memberlakukan norma) yang dilakukan Mahkamah Konstitusi hanyalah menjadi negative legislator (membatalkan norma) atau membiarkan norma yang

\footnotetext{
${ }^{7}$ Martitah, Mahkamah Konstitusi Dari Negative Legislature ke Positive Legislature cetakan pertama,Jakarta:Konstitusi Press, 2013, hlm 56

8 Mahfud MD, Konstitusi Dan Hukum Dalam Kontroversi Isu.cetakan pertama,Jakarta:Rajawali Pers, 2009, hlm 277
} 
diberlakukan oleh lembaga legislatif tetap berlaku dengan menggunakan original intent Undang-Undang Dasar sebagai tolok ukurnya.

\section{Rumusan Masalah}

2.1. Apakah akibat hukum atas putusan Mahkamah Konstitusi Nomor 21/PUUXII/2014.

2.2. Apakah putusan Mahkamah Konstitusi Nomor 21/PUU-XII/2014 tentang penetapan status tersangka menjadi objek dalam Praperadilan telah sesuai dengan kewenangan Mahkamah Konstitusi yang di atur dalam UndangUndang Nomor 24 Tahun 2003 Junto Undang-Undang Nomor 8 tahun 2011 tentang Mahkamah Konstitusi.

\section{Tujuan Penelitian}

3.1. Untuk mengkaji secara mendalam akibat hukum atas putusan Mahkamah Konstitusi Nomor 21/PUU-XII/2014.

3.2. Untuk mengkaji secara mendalam pertimbangan hakim Mahkamah Konstitusi dalam Memberikan Putusan Nomor 21/PUU-XII/2014 tentang uji materi Pasal 77 huruf a KUHAP apakah sesuai dengan kewenangan Mahkamah Konstitusi yang di atur dalam Undang-Undang Nomor 8 Tahun 2011 tentang Mahkamah Konstitusi.

\section{Metode Penelitian}

\subsection{Jenis Penelitian}

Tipe penelitian ini adalah penelitian normatif soerjono sukanto menjelaskan bahwa pada penelitian hukum normatif bahan pustaka merupakan data dasar . terdapat 3 macam bahan pustaka yang di pergunakan penulis yaitu bahan hukum primer merupakan bahan hukum yang mengikat seperti peraturan perundang-undangan ,bahan hukum sekunder seperti pendapat 
para ahli atau para pakar hukum. Serta bahan tersier yaitu bahan hukum yang mendukung bahan hukum primer dan sekunder seperti kamus hukum .

\subsection{Pendekatan Penelitian}

Untuk membahas permasalahan diatas, peneliti menggunakan pendekatan Undang-Undang Nomor 8 Tahun 2011 Tentang Mahkamah Konstitusi Juncto Undang-Undang Nomor 48 Tahun 2009 tentang Kekuasaan Kehakiman. Khususnya dalam Pasal 55 Undang-Undang Nomor 8 Tahun 2011 tentang kewenangan Mahkamah Konstitusi dalam memberikan putusan Sebagai Landasan Yuridis terhadap putusan Mahkamah Konstitusi Nomor 21/PUU-XII/2014 tentang penambah objek tersangka dalam proses Praperadilan.

\section{Hasil Penelitian dan Pembahasan}

5.1. Akibat hukum pemuatan norma baru oleh Mahkamah Konstitusi dalam Putusan Mahkamah Konstitusi Nomor 21/PUU-XII/2014 mengenai pengujian Pasal 77 Huruf a KUHAP

Dasar hukum putusan perkara konstitusi adalah Undang-Undang Dasar 1945 sebagai konstitusi tertulis negara Republik Indonesia. Untuk putusan yang mengabulkan harus di dasarkan pada sekurang-kurang nya dua alat bukti yang sah dan keyakinan hakim bahwa permohonan itu memenuhi alasan dan syarat-syarat Konstitusional sebagaimana dimaksud dalam Konstitusi. Oleh karena itu putusan harus memuat fakta-fakta yang terungkap dan terbukti secara sah di persidangan dan pertimbangan hukum yang menjadi dasar.

Pengambilan putusan dilakukan dengan musyawarah untuk mufakat dalam Rapat Permusyawaratan Hakim memalui sidang pleno tertutup di pimpin oleh ketua sidang. Didalam rapat pengambilan putusan ini setiap Hakim Konstitusi menyampaikan pertimbangan atau pendapat tertulis 
terhadap permohonan (legal opinion), dengan demikian tidak ada suara abstain dalam rapat pengambilan putusan.

Dalam hal putusan tidak dapat dihasilkan melalui musyawarah untuk mufakat maka musyawarah di tunda sampai sidang pleno berikutnya. Musyawarah itu di usahakan sungguh-sungguh untuk mufakat, namun jika tidak tercapai mufakat maka putusan di ambil dengan suara terbanyak.

Putusan Mahkamah Konstitusi diucapakan pada saat sidang pleno terbuka. Mahkamah Konstitusi sebagai putusan pengadilan tingkat pertama dan terakhir berkekuatan hukum tetap dan final. Artinya terhadap putusan tersebut tidak ada upaya hukum lagi dan wajib dilaksanakan. (Pasal 46 (a) dan 47) Undang-Undang Nomor 11 tahun 2011 tentang Mahkamah Konstitusi.

Mahkamah Konstitusi menjatuhkan putusan demi keadilan berdasarkan Ketuhanan Yang Maha Esa seperti juga putusan pengadilan lainnya. Putusan Mahkamah Konstitusi harus memuat hal-hal berikut :

5.1.1. Kepala putusan berbunyi "Demi Keadilan berdasarkan Ketuahan Yang Maha Esa"

5.1.2. Identitas pihak

5.1.3. Ringkasan permohonan

5.1.4. Pertimbangan terhadap fakta yang terungkap

5.1.5. Pertimbangan hukum yang menjadi dasar putusan

5.1.6. Amar putusan

5.1.7. Hari dan tanggal putusan

5.1.8. Nama hakim Konstitusi dan Panitera

Putusan yang telah diucapakan dalam sidang terbuka untuk umum dan

oleh karenanya telah berkekuatan hukum tetap tersebut salinannya kemudian harus disampaikan kepada para pihak paling lambat dalam waktu 7 hari kerja sejak putusan di ucapkan. 
Pengujian Undang-Undang terhadap Undang-Undang Dasar 1945 Hukum Acara Khusus yang mengatur prosedur dan hal-hal lain tterkait dengan pengujian undang-undang di dalam Undang-Undang Mahkamah Konstitusi meliputi sebagai berikut:

5.1.1. Undang-Undang yang dapat di mohon kan pengujian

5.1.2. Pihak yang bertindak dalam permhohonan pengujian UndangUndang

5.1.3. Bentuk pengujian Undang-Undang

5.1.4. Kewajiban Mahkamah Konstitusi menyampaikan salinan permohonan kepada institusi /lembaga negara tertentu (terutama lembaga negara pembentuk Undang-Undang)

5.1.5. Hak Mahkamah Konstitusi meminta keterangan terhadap lembaga negara terkait dengan permohonan.

5.1.6. Materi Putusan

5.1.7. Akibat Putusan pengujian Undang-Undang dan kewajiban Mahkamah Konstitusi setelah putusan.

Didalam praktek ketentuan tersebut tidak dapat menampung permasalahan-permasalah yang timbul. Karena itu berdasarkan pasal 86 Undang-Undang Mahkamah Konstitusi ,Mahkamah Konstitusi yang telah diberikan kewenangan mengatur telah membentuk peraturan Mahkamah Konstitusi nomor 06/PMK/2005.

Didalam Undang-Undang Dasar 1945 tidak terdapat batasan mengenai Undang-Undang yang dapat di mohonkan pengujian. Mengenai UndangUndang yang dapat dimohonkan pengujiannya namun didalam UndangUndang Mahkamah Konstitusi Undang-Undang yang dapat dimohonkan pengujian itu dibatasi hanya Undang-Undang yang diundangkan setelah terjadi nya perubahan Undang-Undang Dasar 1945. Terhadap ketentuan ini Mahkamah Konstitusi dengan putusannya Nomor 004/PUUI/2004,berpendapat tidak sesuai Konstitusi karena itu Mahkamah Konstitusi 
mengesampingkan. Dengan adanya permohonan kepada Mahkamah Konstitusi untuk menguji Pasal tersebut ketentuan dimaksud dinyatakan tidak mempunyai kekuatan mengikat secara Hukum melalui Putusan Mahkamah Konstitusi Nomor 066/PUU-II/2004 perihal Pengujian UndangUndang Nomor 24 Tahun 2003 Pasal 50 tentang Mahkamah Konstitusi .sejak putusan Mahkamah Konstitusi yang terakhir ini maka secara efektif tidak terdapat lagi batasan Undang-Undang yang dapat di mohonkan pengujian nya. $^{9}$

Bentuk pengujian Undang-Undang meliputi pengujian formil dan materiil. pengujian formil dimaksudkan sebagai bentuk pengujian berkenaan dengan pembentukan Undang-Undang yang di anggap tidak memenuhi ketentuan berdasarkan Undang-Undang Dasar 1945. Yakni mengenai pembahasan, pengesahan, pengundangan dan pemberlakuan.

Dimulai sejak Pro kontra putusan hakim pengadilan Negeri Jakarta Nomor 04/Pid.Prap/2015/PN.Jaksel oleh hakim tunggal Praperadilan Sarpin rizaldi yang mengabulkan permohonan Praperadilan Komjen Pol. Budi gunawan yang menyatakan penetapan Budi Gunawan sebagai tersangka oleh Komisi Pemberantasan Korupsi adalah tidak sah.

Banyak yang mengkritisi Keputusan ini karena dalam KUHAP tidak mengatur penetapan tersangka dapat di Prapredilan Perlu di ketahui bahwa sistem Hukum di Indonesia tidak sama dengan sistem hukum Anglo Saxon yang menganut aliran bahwa hakim boleh menciptakan hukum, (judge made law) hal ini sejalan dengan ketentuan Pasal 20 alggemene bepalingen van wetgeving voor Indonesie (AB-AB masih berlaku sepanjang belum di cabut secara tegas oleh Undang-Undang berdasarkan aturan peralihan UndangUndang Dasar 1945, yang menyatakan "Hakim harus mengadili berdasarkan Undang-Undang".

\footnotetext{
${ }^{9}$ Ahmad Fadlil Sumadi ,"Hukum Acara Mahkamah Konstitusi Teori Dan Praktik"Jurnal Konstitusi,Edisi No. 8 Vol. 6 (2011), hlm 853-859.
} 
Hal ini berarti bahwa dalam hukum di Indonesia hakim dilarang menafsirkan lebih dari yang seharusnya jika sudah jelas pengaturannya. Namun bukan berarti Hakim menjadi tidak bebas dalam menjalankan kewenangan nya. Hakim di perbolehkan untuk menafsirkan lebih luas suatu peraturan di kala peraturan tersebut tidak jelas maksutnya, Hakim di perbolehkan membuat kaedah Hukum di saat terjadi kekosongan Hukum.

Secara keseluruhan berdasarkan Sistem hukum di Indonesia yaitu positivesme hukum, tentang Praperdilan sudah di atur dengan jelas dalam Pasal 77 KUHAP sehingga Hakim Praperadilan seharus nya tidak dapat mempergunakan kewenangan yang di berikan kepadanya melalui Undang Undang Nomor 48 Tahun 2009 tentang Kekuasaan Kehakiman .

Untuk menafsirkan hukum lebih dari yang sudah di atur dalam Pasal 77 KUHAP. Karena kewenangan untuk menafsirkan juga di batasi yaitu hanya dapat di gunakan ketika hukum yang mengatur tidak ada atau hukum yang menagatur tidak jelas.

Sejak di keluarkan nya putusan tersebut terjadi Pro dan Kontra dalam masyarakat serta pertentangan dari para ahli hukum sehingga menimbulkan dinamika hukum baru dalam peradilan di Indonesia, banyak tersangka terutama dalam kasus korupsi menjadikan Praperadilan sebagai jalan untuk melepaskan diri dari jerat hukum penyidik. Mereka merasa bahwa penetapan tersangka pada dirinya tidak berdasarkan alat bukti dan melanggar hak asasi manusia. padahal penyidik dalam hal ini Komisi Pemberantasan Korupsi dalam menentukan status tersangka selalu dengan alat bukti permulaan yang berkekuatan hukum.

Pengujian Pasal 77 huruf (a) KUHAP mengenai objek Praperadilan dijukan oleh Bachtiar Abdul Fattah pada kepaniteraan Mahkamah Konstitusi pada tanggal 17 Februari 2014 karena dianggap bertentangan dengan Pasal 1 ayat 3 ,Pasal 28 (d) ayat 1, dan Pasal 28 (i) ayat 5 Undang-Undang Dasar 1945. 
Permohonan tersebut dicatat dalam buku register Mahkamah Konstitusi, dengan Nomor 21/PUU-XII-2014 pada tanggal 26 Februari 2014. Adapun alasan pemohon sebagai berikut:

Pertama bahwa proses hukum untuk menguji upaya paksa yang di lakukan penyidik adalah Pengadilan Negeri berwenang untuk memeriksa dan memutus sesuai dengan ketentuan yang diatur dalam Undang-Undang ini tentang sah atau tidaknya penangkapan penahanan penghentian penyidikan atau penghentian penuntutan serta ganti kerugian dan atau rehabilitasi bagi seseorang yang perkara pidana nya dihentikan pada tingkay penyidikan atau penuntutan.

Kedua bahwa konsep Praperadilan berdasarkan Pasal 77 huruf (a) KUHAP, yang terbatas pada memberikan penilaian terhadap sah atau tidaknya penangkapan penahanan penghentian penyidikan atau penghentian penuntutan jelas tidak sepenuhnya memberikan perlindugan yang cukup kepada seseorang kepada seorangan tersangka dari pelanggaran terhadap hak asasi manusia yang dapat dilakukan oleh penyidik Penuntut Umum atau bahkan Hakim.

Ketiga bahwa konsep Praperadilan ini pada hakikatnya adalah proses melindungi Hak Asasi Manusia berkenaan dengan penggunaan upaya paksa yang dilakukan oleh penegak hukum .karena memalui Praperadilan itulah akan dinilai kesesuaian proses penggunaan upaya paksa tersebut dengan prosedur yang ditentukan dalam Undang-Undang.

Keempat, bahwa pada hakikatnya kewenangan Praperadilan adalah untuk menguji setiap upaya yang mengurangi hak asasi seseorang. bahwa Praperadilan berwenang untuk mengadili dan memutus permohonan sah atau tidaknya penangguhan sah atau tidak nya pemblokiran sah atau tidak nya pengguunaan police line karena kewenangan hakim praperadilan untuk menilai seluruh proses pengunaan upaya paksa untuk mengurangi hak asasi seseorang. 
Kelima, bahwa sebagai mana di tuangkan oleh Mahkamah Konstitusi melalui Putusan Nomor 65/PUU-IX/2011 yang pada halaman 30 menyatakan filosi di adakan Pranata Praperadilan yang justru menjamin hak-hak tersangka terdakwa sesuai dengan harkat dan martabat sebagai manusia. Sehingga bagi putusan Praperadilan yang sudah berkekuatan hukum tetap tidak dapat dilakukan banding atau kasasi dan tentu saja putusan Praperadilan tidak dapat di batalkan atau dianggap batal oleh suatu surat keterangan .

Keenam bahwa ketidak mampuan pranata Praperadilan dalam mengikuti perkembangan hukum terbukti dari rumusan Pasal 77 huruf (a) KUHAP yang sangat sempit dan limitatif sehingga tidak mencangkup seleuruh upaya paksa yang dapat dilakukan oleh penyidik. Rumusan yang bersifat terbatas dan limitatif tersebut jelas bertentangan dengan prinsip due procces of law karena sejumlah upaya paksa yang tidak di sebutkan dalam Pasal 77 huruf (a) KUHAP menjadi tidak diuji keabsahaannya melalui praperadilan sehingga bertentangan dengan Pasal 1 ayat 3 Pasal 28 d ayat 1 Pasal 28 (i) ayat 5 Undang-Undang Dasar 1945.

Ketujuh bahwa mengacu pada uraian diatas agar materi muatan Pasal 77 huruf (a) sesuai dengan prinsip due procces of law yang dijamin dalam Pasal 1 ayat 3 Pasal 28 (d) ayat 1 Pasal 28 (i) ayat 5 Undang-Undang 1945 maka materi muatan Pasal 77 huruf a harus juga memuat upaya Paksa lain nya sehingga Pasal 77 huruf a kuhap harus dinyatakan bertentangan dengan Undang-Undang Dasar 1945 secara bersyarat (conditionally inconstitusional) dan tidak mempunyai kekuatan Hukum mengikat sepanjang tidak dimaknai mencangkup sah atau tidak nya penetapan tersangka, pengeledahan penyitaan pemeriksaan surat.

Berdasarkan permohonan tersebut dalam petitum pemohon memohon agar majelis hakim konstitusi dalam putusan nya menyatakan bahwa Pasal 77 huruf (a) KUHAP bertentangan dengan Undang-Undang Dasar 1945. 
Pemuatan norma baru oleh Mahkamah Konstitusi dalam Putusan Mahkamh Konstitusi Nomor 21/PUU-XII/2014 mengenai Pengujian Pasal 77 huruf (a) KUHAP dapat menimbulkan beberapa implikasi hukum diantaranya adalah Implikasi terhadap pengajuan Praperadilan terkait penetapan tersangka.

5.2. Akibat Hukum yang pertama Semakin Banyaknya Gugatan Praperadilan yang bertujuan untuk melepaskan diri dari penetapan tersangka.

Dimasukkannya penetapan tersangka kedalam objek praperadilan oleh Mahkamah Konstitusi menimbulkan banyak gugatan Praperadilan yang dilakukan oleh tersangka terkait penetapan dirinya sebagai tersangka Yang bertujuan untuk melepaskan diri dari penetapan tersangka atau dalam proses penyelidikan yang dilakukan oleh penegak Hukum, diantaranya adalah:

Pertama, gugatan Praperadilan yang dilakukan oleh Suroso Atmo Wartoyo. "Suroso menggugat penetapan dirinya sebagai tersangka atas kasus suap pengadaan zat tambahan bahan bakar TEL (tetraethyl lead) 2004 dan 2005. Suroso disangka mengantongi uang suap dari Direktur PT Soegih Indrajaya, Willy Sebastian Liem." 10

Hakim F. Riyadi Sunindyo pada tanggal 16 April 2015 dalam Putusan Nomor 18/Pid.Prap/2015/PN.Jkt.SEL Tahun 2015 memutuskan bahwa gugatan Praperadilan yang diajukan oleh pemohon ditolak.

Kedua, Praperadilan yang diajukan oleh Jero Wacik. "Jero Wacik ditetapkan tersangka oleh Komisi Pemberantasan Korupsi atas kasus dugaan penyalahgunaan wewenang dalam kapasitasnya sebagai Menteri Kebudayaan dan Pariwisata 2008-2011 serta Menteri ESDM 2011-2013. Tak

10 Deny Irwanto, Gugatan Praperadilan Suroso Atmo Martoyo Ditolak PN Jaksel,http://news.metrotvnews.com, diakses Tanggal 22 Mei 2017. 
terima dengan penetapan tersangka itu, politikus Partai Demokrat itu akhirnya mengajukan praperadilan." 11

Hakim Sihar Purba pada tanggal 28 April 2015 dalam pokok perkara menyatakan bahwa permohonan yang diajukan oleh pemohon ditolak untuk seluruhnya.

Ketiga, permohonan praperadilan yang diajukan oleh Ilham Arief Sirajuddin. "Komisi Pemberantasan Korupsi mengumumkan bahwa Ilham ditetapkan sebagai tersangka kasus dugaan korupsi dalam kerja sama kelola dan transfer PDAM Kota Makassar tahun 2006 sampai Tahun 2012 yang diduga menimbulkan kerugian negara sampai Rp 38,1 miliar dan dijerat dengan Pasal 2 ayat 1 atau Pasal 3 UU Tipikor jo Pasal 55 ayat 1 ke-1 KUHAP." Permohonan Praperadilan Ilham Arief Sirajuddin diputus oleh Hakim Yuningtyas, S.H.M.H., melalui Putusan Nomor 32/Pid.Prap/2015/PN.Jkt.Sel Tahun 2015 pada tanggal 12 Mei 2015 yang dalam pokok perkara diantaranya menyatakan bahwa penetapan tersangka atas diri pemohon yang dilakukan oleh Komisi Pemberantasan Korupsi adalah tidak sah.

Keempat, gugatan Praperadilan yang dilakukan oleh Dahlan Iskan. Dahlan Iskan menggugat Praperadilan Kejaksaan Tinggi DKI Jakarta atas penetapannya sebagai tersangka dalam kasus tindak pidana dugaan korupsi pembangunan 21 Gardu Induk di Jawa, Bali, dan Nusa Tenggara Barat pada periode 2011-2013 senilai Rp1,063 triliun. Permohonan Praperadilan tersebut didaftarkan pada Kepaniteraan Pengadilan Negeri Jakarta Selatan pada tanggal 2 Juli 2015 dan diputus oleh Hakim Lendriaty Jenis, S.H., M.H. pada tanggal 4 Agustus 2015 dengan Putusan Nomor 67/Pid.Prap./2015/PN. Jkt. Sel. yang amar putusannya diantaranya 
menyatakan bahwa penetapan tersangka atas diri pemohon yang dilakukan oleh termohon adalah tidak sah.

kelima, gugatan Praperadilan yang dilakukan oleh Nur Alam. Nur Alam adalah Gubernur Sulawesi Tenggara Non-aktif. Nur Alam mengajukan permohonan Praperadilan atas dirinya lantaran tidak terima atas penepatan dirinya sebagai tersangka. Dirinya ditetapkan sebagai tersangka pada 23 Agustus 2016. Namun sampai dengan dirinya ditetapkan sebagai tersangka, dirinya tidak pernah dimintai keterangan oleh Komisi Pemberantasan Korupsi. ${ }^{12}$ Permohonan praperadilan tersebut diajukan di Pengadilan Negeri Jakarta Selatan pada tanggal 16 September 2016 dan diputus oleh Hakim Wayan Karya, S.H., M.Hum. pada tanggal 12 Oktober 2016 melalui Putusan Nomor 127/Pid.Prap/2016/PN.JKT.Sel. yang menyatakan bahwa permohonan praperadilan yang diajukan oleh Nur Alam ditolak untuk seluruhnya.

Keenam, gugatan Praperadilan yang diajukan oleh Dahlan Iskan. Dahlan Iskan ditetapkan sebagai tersangka atas kasus dugaan penjualan aset saat menjabat sebagai Direktur Utama PT Panca Wira Usaha (PWU). Majelis hakim Pengadilan Negeri Surabaya menolak Praperadilan yang diajukan mantan Menteri Badan Usaha Milik Negara Dahlan Iskan. "Menyatakan permohonan praperadilan pemohon gugur," kata hakim tunggal Ferdinandus saat membacakan putusan gugatan praperadilan pada hari Kamis tanggal 24 November 2016. ${ }^{13}$

ketujuh, gugatan Praperadilan yang diajukan oleh La Nyalla Mattaliti. La Nyalla Mattaliti ditetapkan sebagai tersangka pada tanggal 16 Maret 2016 berdasarkan Surat Penetapan Tersangka Nomor Kep.11/05/Fd.1/03/2016 karena disangka melakukan Tindak Pidana Korupsi penggunaan dana hibah

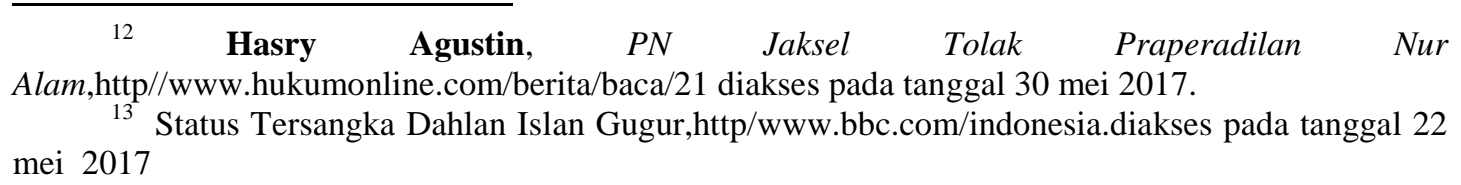


pada Kamar Dagang dan Industri Provinsi Jawa Timur Tahun 2012 untuk pembelian Initial Public Offering (IPO) Bank Jatim. Pada tanggal 18 Maret 2016 La Nyalla Mattaliti mengajukan permohonan praperadilan atas penetapan tersangka tersebut, dan diputus oleh Hakim Ferdinandus pada tanggal 12 April 2016 dengan putusan Nomor 19/Pra.Per./2016/PN.SBY. amar putusan dalam pokok perkara diantaranya menyatakan bahwa penetapan tersangka atas pemohon adalah tidak sah. ${ }^{14}$

Beberapa contoh kasus permohonan praperadilan diatas, membuktikan bahwa dimasukkannya norma penetapan tersangka kedalam objek praperadilan oleh Putusan MK Nomor 21/PUU-XII/2014, membuat banyak tersangka mengajukan Praperadilan.

5.3. Akibat hukum kedua terjadi permasalah Hukum baru yaitu Perang antara Praperadilan VS Surat Perintah Penyidikan (spindik baru)

Hakim tunggal pada Pengadilan Negeri Surabaya, Ferdinandus mengabulkan permohonan Praperadilan yang diajukan oleh La Nyalla Mattalitti, yang dibacakan pada tanggal 12 April 2016. Beberapa bukti yang diajukan oleh Kejaksaan Tinggi Jawa Timur, dikesampingkan oleh Hakim. Hakim Ferdinandus menunjuk bukti audit Badan Pengawas Keuangan dan Pembangunan, yang menyatakan kerugian negara atas korupsi dana hibah Kadin Jawa Timur dinyatakan tidak ada, karena dana hibah yang digunakan untuk membeli saham PT. Bank Jatim, sudah dikembalikan.

Pengembalian menurut Hakim sudah dilakukan sebelum keluarnya putusan dari Pengadilan Tindak Pidana Korupsi. Hakim juga merujuk pendapat ahli Hukum Pidana Universitas Gadjah Mada, Edward Omar Syarif yang mengatakan bahwa bila pengembalian dilakukan sebelum penyidikan,

${ }^{14}$ Kejari surabaya,” Praperadilan Laa Nyalla sampai berapa babak?” dalam http://www.Kejari sby.co.id /Artikel-Praperadilan-La nyalla-sampai-berapa-babak Diakses pada 27 januari 2017. 
maka bukan tindak pidana. Dikabulkannya permohonan Praperadilan oleh La Nyalla Mattalitti oleh Pengadilan Negeri Surabaya, menarik sekali dikaji dari aspek yuridisnya, oleh karena pihak Kajati Jawa Timur telah berusaha untuk menerbitkan Sprindik baru sebagai penetapan tersangka, bahkan Kepala Kejaksaan Tinggi Jawa Timur mempersilahkan La Nyalla melakukan gugatan lagi, dan jika Kajati kalah lagi, dia tetap akan mengeluarkan Sprindik baru lagi.

Drama praperadilan Laa Nyaalla M. Telah sampai ke babak ketiga. dengan skor 3-0 untuk kemenangan La nyalla Ini merupakan perang antara Praperadilkan VS Surat perintah Penyidikan (sprindik baru). Sementara dalam Praperadilan jilid 1 sprindik umum(yang belum menetapkan nama tersangka) di tolak oleh hakim tunggal efran basuring. Bahkan dianggap ne bis in idem. Karena untuk perkara korupsi dana hibah pemprov jatim kepada kadin sudah diadili oleh ketua kadin jatim diar kusuma putra dan nelson sembiring.

Pertanyaan nya sekarang dapatkan kejati menerbitan sprindik baru lagi setelah di nyatakan kalah lagi dalam praperadilan jilid 3 ini? Sampai berapa kali penyidik dapat mengeluarkan sprindik baru atau sebalik nya dapatkan tersangka mengajukan Praperadilan lagi dan sampai berapa kali batasan nya? Karena sampai dengan saat ini belum ada payung Hukum yang mengatur batasan mengajuan praperadilan dan pengeluaran sprindik baru oleh penyidik atau penuntut umum.

Sebelum putusan hakim sarpin pada permohonan komjen Budi Gunawan dan di kuatkan putusan Mahkamah Konstitusi Nomor 21/PUUXII/2014 tidak pernah ada kasus bolak -balik Praperadilan setelah penetapan tersangka menjadi objek Praperadilan baru muncul fenoma hukum seperti ini. Begitu pula sebaliknya pengeluaran sprindik berkali-kali juga terjadi pasca putusan Mahkamah Konstitusi ini.

Kejati sengaja tidak memilih jalur Peninjauan Kembali (PK),karena kalau Peninjauan Kendali bisa sampai setahun. Dikaji dari argumentasi Kajati 
Jatim tidak akan memilih jalur Peninjauan Kembali (PK), menurut penulis, argumentasi tersebut juga keliru, oleh karena telah terbit Putusan Mahkamah Konstitusi yang melarang Jaksa melakukan PK. Amar putusan Mahkamah Konstitusi Nomor 33/PUU-XIV/2016 atas permohonan pengujian oleh pemohon Anna Boentaran mengenai uji material Pasal 263 ayat (1) UndangUndang No. 8 Tahun 1981 tentang KUHAP, "Mengabulkan permohonan Pemohon, Pasal 263 ayat (1) KUHAP bertentangan dengan Undang-Undang Dasar 1945 dan tidak mempunyai kekuatan hukum mengikat secara bersyarat, yaitu sepanjang dimaknai lain selain yang secara eksplisit (tegas) tersurat dalam norma a quo." 17

Menurut Pasal 263 ayat (1) KUHAP, dinyatakan bahwa "Terhadap putusan pengadilan yang telah memperoleh kekuatan hukum tetap, kecuali putusan bebas atau lepas dari segala tuntutan hukum, terpidana atau ahli warisnya dapat mengajukan permintaan peninjauan kembali kepada Mahkamah Agung."

Ketentuan tersebut secara tegas menyatakan yang dapat mengajukan peninjauan kembali hanya terpidana atau ahli warisnya, dan tidak ditentukan Jaksa berhak mengajukan peninjauan kembali. Jaksa Agung H.M. Prasetyo, menyatakan putusan Mahkamah Konstitusi yang melarang jaksa mengajukan upaya hukum Peninjauan Kembali merupakan langkah mundur dalam penegakan hukum di Indonesia."15 Tetapi, wakil Ketua Komisi Pemberantasan Korupsi , Alex marrwata, menyatakan "Jika Mahkamah Agung sebagai benteng terakhir keadilan belum bersih dari unsur hakim lacur, maka larangan mengajukan Peninjauan Kembali oleh jaksa akan mereduksi pencari keadilan." ${ }^{16}$ Meskipun menurut Pasal 263 ayat (1) KUHAP ditentukan yang berhakmengajukan Peninjauan Kembali ialah terpidana atau ahli

$15 \mathrm{http} /$ /nasional.harianterbit.com/nasional/2016/05/16/61"Jaksa Dilarang Ajukan PK,MK Dinilai Lindungi Koruptor," di akses pada 30 mei 2017

$16 \mathrm{http} /$ detik.news/berita/3212914"Jaksa Dilarang PK,ini Mereduksi Pencari Keadilan," Diakses pada 30 mei 2017 
warisnya tetapi menurut penulis, pada aparat kejaksaan berdasarkan UndangUndang Nomor 16 Tahun 2004 tentang Kejaksaan Republik Indonesia, terdapat kewenangan mewakili negara sebagai Pengacara Negara sebagaimana ditentukan pada Pasal 30 ayat (2) yang menyatakan "Di bidang perdata dan Tata Usaha Negara, kejaksaan dengan kuasa khusus dapat bertindak baik di dalam maupun di luar pengadilan untuk dan atas nama negara atau pemerintah."

Pembahasan tentang Peninjauan Kembali berkaitan dengan pernyataan Kajati Jawa Timur, Maruli Hutagalung dalam kasus La Nyalla Mattalitti yang sengaja tidak memilih jalur Peninjauan Kembali karena waktunya lama. Dikaji dari ketentuan Pasal 263 ayat (1) KUHAP, maka yang berhak mengajukan Peninjauan Kembali hanya terpidana dan atau ahli warisnya, sebagaimana ketentuan Pasal 263 ayat-ayatnya KUHAP menyatakan bahwa:

(1) Terhadap putusan pengadilan yang telah memperoleh kekuatan hukum tetap, kecuali putusan bebas atau lepas dari segala tuntutan hukum, terpidana atau ahli warisnya dapat mengajukan permintaan peninjauan kembali kepada Mahkamah Agung.

(2) Permintaan Peninjauan Kembali dilakukan atas dasar:

a. Apabila terdapat keadaan baru yang menimbulkan dugaan kuat, bahwa jika keadaan itu sudah diketahui pada waktu sidang masih berlangsung, hasilnya akan berupa putusan bebas atau putusan lepas dari segala tuntutan hukum atau tuntutan penuntut umum tidak dapat diterima atau terhadap perkara itu diterapkan ketentuan pidana yang lebih ringan;

b. Apabila dalam pelbagai putusan terdapat pernyataan bahwa sesuatu telah terbukti, akan tetapi hal atau keadaan sebagai dasar dan alasan putusan yang telah terbukti itu, ternyata telah bertentangan satu dengan yang lain.

c. Apabila putusan itu dengan jelas memperlihatkan suatu kekhilafan hakim atau suatu kekeliruan yang nyata.

(3) Atas dasar alasan yang sama sebagaimana tersebut pada ayat (2), terhadap suatu putusan pengadilan yang telah memperoleh kekuatan hukum tetap dapat diajukan permintaan peninjauan kembali apabila dalam putusan itu telah dinyatakan terbukti akan tetapi tidak diikuti oleh suatu pemidanaan. Kewenangan Jaksa di bidang perdata dan tata usaha negara dengan kuasa khusus 
mewakili negara atau pemerintah, ditemukan di dalam ketentuan tindak pidana korupsi, yang menunjukkan pergeseran tindak pidana korupsi sebagai tindak pidana khusus bergeser ke perdata sebagaimana ditentukan dalam Pasal 38C Undang-Undang No. 31 Tahun 1999 jo. Undang-Undang Nomor. 20 Tahun 2004 tentang Pemberantasan Tindak Pidana Korupsi, yang menyatakan bahwa "Apabila setelah putusan pengadilan telah memperoleh kekuatan hukum tetap, diketahui masih terdapat harta benda milik terpidana yang diduga atau patut diduga juga berasal dari tindak pidana korupsi yang belum dikenakan perampasan untuk negara sebagaimana dimaksud dalam Pasal 38B ayat (2), maka negara dapat melakukan gugatan perdata terhadap terpidana dan atau ahli warisnya."Apabila dicermati kewenangan Jaksa selaku Pengacara Negara/Pemerintah mengajukan Peninjauan Kembali tersebut, sebenarnya substansi yang terkandung didalamnya adalah melalui kewenangan Jaksa mengajukan Peninjauan Kembali, maka harta kekayaan terpidana misalnya dapat disita untuk negara. Ketentuan yang mirip juga ditemukan dalam Undang-Undang Nomor 8 Tahun 2010 tentang Pencegahan dan Pemberantasan Tindak Pidana Pencucian Uang, yang pada Pasal 81 menyatakan bahwa "Dalam hal diperoleh bukti yang cukup bahwa masih ada Harta Kekayaan yang belum disita, hakim memerintahkan jaksa penuntut umum untuk melakukan penyitaan Harta Kekayaan tersebut." 17

Pembahasan tentang dikabulkannya permohonan Praperadilan oleh La Nyalla Mattalitti oleh Pengadilan Negeri Surabaya, jika dikaji dari ketentuan dalam KUHAP, sebenarnya pihak Kajati Jawa Timur rela penetapan La Nyalla Mattalitti sebagai tersangka oleh Kajati Jawa Timur tersebut diartikan tidak sah, dan dengan demikian status tersangka tersebut dengan sendirinya berubah menjadi bukan tersangka lagi. Putusan Praperadilan oleh Pengadilan Negeri Surabaya pada kasus tersebut ternyata ditanggapi oleh Kajati Jawa Timur dengan menerbitkan Sprindik baru pada subjek dan objek yang sama, yang memperlihatkan sikap Kajati memiliki alasan kuat untuk menetapkan status tersangka dan melakukan penuntutan. Alasan kuat yang demikian tampak dan seakan-akan memaksakan agar status terpidana La Nyalla

${ }^{17}$ Pasal 81 UU Nomor 8 Tahun 2010 tentang Pencegahan dan Pemberantasan Tindak Pidana Pencucian Uang 
Mattalitti dipertahankan dan dilanjutkan proses hukumnya, tanpa mengabaikan bahwa kemungkinan penetapan tersangka tersebut dapat terjadi kekeliruan dan kekhilafan oleh pihak Kejaksaan. Aparat penegak hukum, seperti Kajati Jawa Timur dapat saja melakukan kekeliruan dan atau kekhilafan, oleh karena aparat yang bersangkutan adalah manusia biasa.

Praperadilan selain sebagai implementasi hak hak tersangka sebagai hak asasi manusia, juga berfungsi sebagai alat kontrol terhadap aparat penegak hukum, khususnya penyidik atau penuntut umum agar terhindar dari tindakan sewenang-wenang, melanggar hukum dan lain sebagainya. Pada kasus dikabulkannya permohonan Praperadilan, menyebabkan dua lembaga penegak hukum bersikap berseberangan tetapi jika dikaji secara Yuridis, masing-masing lembaga penegak hukum tersebut sama-sama memiliki dasar hukum yang kuat dalam bersikap dan bertindak seperti dengan menerbitkan Sprindik baru, oleh karena tidak ada ketentuan yang mengatur berapa banyak Sprindik yang dapat diterbitkan untuk subjek dan objek yang Persoalan lainnya dari kasus tersebut, ialah ketika terbitnya penetapan La Nyalla Mattalitti sebagai tersangka sebelum sidang Praperadilan,yang bersangkutan berada di luar negeri (Singapura) sementara permintaan pencegahan dan pencekalan (Cekal) kepada pejabat imigrasi terlambat oleh karena yang bersangkutan sudah berada di luar negeri. Langkah yang ditempuh La Nyalla Mattalitti ke luar negeri merupakan lengkap tepat, oleh karena jika berada di dalam negeri akan dapat dilakukan upaya paksa seperti dijemput secara paksa. Padahal, sebagai pejabat publik kerena memimpin PSSI dan Kadin Jawa Timur sekaligus sebagai pengusaha terkemuka, persoalan nama baik menjadi taruhannya.

Pembahasan ini jika dari aspek hukum dengan dikabulkannya putusan praperadilan yang dimohonkan oleh La Nyalla Mattalitti berarti dengan sendirinya pihak La Nyalla Mattalitti diputuskan tidak sahnya penetapan status sebagai tersangka oleh Kajati Jawa Timur, namun pada beberapa 
kasus Praperadilan, menurut Amir Burhanuddin, salah seorangkuasa hukum La Nyalla Mattalitti dikemukakan contoh kasus Praperadilan yang sudah diputus dan tidak dibuka lagi, seperti kasus Dahlan Iskan yang ditangani Kajati DKI Jakarta, Budi Gunawan yang ditangani Komisi Pemberantasan Korupsi, Hadi Purnomo, mantan Dirjen Pajak, berhenti tidak ada Sprindik baru. $^{18}$

Berdasarkan beberapa putusan Praperadilan tanpa diterbitkannya Sprindik baru tersebut di atas, telah menempatkan dua aparat penegak hukum yang saling berseberangan dan saling bertentangan di dalam menyikapi kasus yang subjeknya sama dan objeknya sama pula. Sebenarnya terdapat dua Sprindik yang diterbitkan oleh Kajati Jawa Timur, yang pertama ialah Surat Perintah Penyidikan No. Print-86-0.5/Fd.1/01/2016 tertanggal 27 Januari 2016 terhadap Wakil Ketua Umum Kadin Jawa Timur, Diar Kusuma Putra yang gugatan Praperadilannya juga dikabulkan oleh Hakim Tunggal Pengadilan Negeri Surabaya, Efran Basuning dengan objek status tersangkanya ialah perkara dana hibah serta kasus berikutnya dengan Surat Perintah Penyidikan No. Print- 120/0.5/Pd.1/02/2016 tertanggal 15 Februari 2016.

Menurut Erfan Basuning, putusan hakim atas gugatan Praperadilan La Nyalla harus dipatuhi, apalagi praperadilan kasus hibah Kadin sudah diajukan dua kali dan dua-duanya dikabulkan oleh Hakim. ${ }^{19}$ Pembahasan ini menemukan kedua lembaga penegak hukum bertolak belakang dalam menyikapi persoalan Praperadilan yang tidak hanya dikaji berdasarkan ketentuan Undang- Undang No. 16 Tahun 2004 tentang Kejaksaan Republik Indonesia, mengingat kedua peraturan perundang-undangan tersebut dijadikan dasar hukum bagi kedua lembaga penegak hukum sehubungan

\footnotetext{
${ }^{18}$ http//Surabaya.tribunnews.com/2016/04/13”Ini Sikap La Nyalla Terkait Keluarnya Sprindik Baru Kajati Jatim,"diakses pada 30 mei 2017

$19 \mathrm{http} / /$ Beritacenter.com/news/52759"Gugatan Praperadilan Kadin di Kabulkan Hakim Surabaya,"diakses pada 30 mei 2017
} 
dengan Praperadilan. Berdasarkan pembahasan ini menurut penulis terdapat kesenjangan antara praktik (das sein) dengan seharusnya (das sollen) karena pengaturan dan aspek-aspek terkait dengan Praperadilan pengaturannya satu dan lainnya tidak sinkron, tidak harmonis, bertentangan dan lain sebagainya yang berakibat di antara aparat penegak hukum dikatakan ada yang menyalahgunakan wewenang atau kekuasaan, melakukan perbuatan melawan hukum dan lain sebagainya. Dari kedudukan dan kewenangan Kejaksaan menurut Undang-Undang No. 16 Tahun 2004 tentang Kejaksaan, ditentukan tugas dan wewenangnya melakukan penuntutan, dan penyidikan terhadap tindak pidana tertentu berdasarkan undang-undang (Pasal 30 ayat (1) huruf a dan huruf d), yang mendasari penuntutan dan penyelidikan pada berbagai tindak pidana tertentu yang merupakan tindak pidana khusus seperti tindak pidana korupsi, tindak pidana pencucian uang dan lain sebagainya. Berdasarkan pada ketentuan-ketentuan tersebut, Kajati Jawa Timur melakukan penyelidikan dan penuntutan terhadap kasus dana hibah Kadin Jawa Timur dan menetapkan para tersangkanya, khususnya La Nyalla Mattalitti sebagai tersangka kasus tersebut. Penulis dapat menerima argumentasi hukum pihak Kajati Jawa Timur, oleh karena terhadap perkaraperkara yang menjadi bagian dari tindak pidana khusus tersebut, terdapat pula upaya hukum bagi kejaksaan untuk bertindak sebagai pengacara negara/pemerintah, untuk dan atas nama negara pemerintah secara hukum berperan mengembalikan kerugian keuangan negara.

Jaksa sebagai pengacara negara/pemerintah, diatur secara jelas pada Pasal 30 ayat (2) Undang-Undang No. 16 Tahun 2004, yang menyatakan bahwa "Di bidang perdata dan tata usaha negara, kejaksaan dengan kuasa khusus dapat bertindak baik di dalam maupun di luar pengadilan untuk dan atas nama negara atau pemerintah. Ketentuanini dipertegas pula dalam beberapa peraturan perundangan tindak pidana khusus, baik tindak pidana korupsi maupun tindak pidana pencucian yang berdasarkan pergeseran kasus 
yang semula adalah tindak pidana, bergeser menjadi perdata sebagaimana yang telah penulis jelaskan sebelumnya.

5.4. Implikasi Putusan MK No 21 /PUU-XII/2014 VS Pasal 40 Undang-Undang Nomor 30 Tahun 2002 Tentang Komisi Pemberantasan Korupsi

Implikasi terhadap hukum acara pidana. Putusan Mahkamah Konstitusi Nomor 21/PUU-XII/2014 dalam menguji Pasal 77 huruf (a) KUHAP dapat menimbulkan norma dalam Pasal 77 huruf (a) KUHAP tersebut bertambah, karena Putusan MK langsung memperoleh kekuatan hukum tetap sejak diucapkan dan tidak ada upaya hukum yang dapat ditempuh (final and binding), serta mengikat untuk umum (erga omnes) 28 sebagaimana diatur dalam Pasal 24C ayat (1) Undang-Undang Dasar 1945 yang menyatakan bahwa "Mahkamah Konstitusi berwenang mengadili pada tingkat pertama dan terakhir yang putusannya bersifat final untuk menguji undang-undang terhadap Undang-Undang Dasar 1945 " Hal tersebut juga diatur dalam Pasal 47 Undang -Undang Mahkamah Korupsi. Hal ini berarti, berdasarkan Putusan Mahkamah Korupsi tersebut objek Praperadilan menjadi bertambah, termasuk penetapan tersangka, penggeledahan, dan peyitaan.

Pasal 77 huruf (a) merupakan satu kesatuan yang saling berhubungan dengan pasal-pasal yang lain dalam KUHAP. Ditambahnya objek praperadilan dalam Pasal 77 huruf a oleh Putusan MK Nomor 21/PUUXII/2014 berdampak pula terhadap pasal-pasal yang lain dalam KUHAP, yang mana pasal-pasal dalam KUHAP yang mengatur tentang praperadilan berdasarkan putusan Mahkamah Konstitusi tersebut norma penetapan tersangka, penggeledahan, dan penyitaan, juga harus ikut ditambahkan.

Selain berimplikasi terhadap aturan-aturan dalam KUHAP, penambahan norma dalam Pasal 77 huruf a oleh oleh MK melalui Putusan Nomor 21/PUU-XII/2014 juga berimplikasi terhadap peraturan acara pidana lain diluar KUHAP, diantaranya adalah Pasal 40 UU Nomor 30 Tahun 2002 tentang Komisi Pemberantasan Korupsi yang Menyatakan "Komisi 
Pemberantasan Korupsi tidak berwenang mengeluarkan surat penghentian penyidikan dan penuntutan dalam perkara tindak pidana korupsi." UndangUndang Nomor 30 tahun 2002 tentang Komisi Pemberantasan Korupsi merupakan pengkhususan dari KUHAP. Berdasarkan asas lex specialis derogate legi generalis yang berarti peraturan perundang-undangan yang khusus mengalahkan peraturan perundang-undangan yang umum, ${ }^{20}$ seharusnya dimasukkannya penetapan tersangka dalam Pasal 77 huruf a KUHAP tidak berpengaruh terhadap UU KPK karena UU KPK merupakan Undang-Undang khusus. Tetapi, dimasukkannya penetapan tersangka sebagai objek praperadilan, dapat membuat orang yang ditetapkan sebagai tersangka tindak pidana korupsi mengajukan Praperadilan.

Dikabulkannya permohonan praperadilan tersangka korupsi atas penetapannya sebagai tersangka, tidak menutup kemungkinan hakim praperadilan akan memutus bahwa penyidikan terhadap pemohon atas penetapannya sebagai tersangka adalah tidak sah dan memerintahkan kepada penyidik Komisi Pemberantasan Korupsi untuk menghentikan penyidikan, sebagaimana terdapat dalam Putusan PN Jakarta Selatan Nomor 04/Pid.Prap/2015/PN.JKT.Sel. Tahun 2015. ${ }^{21}$

Putusan PN Jakarta Selatan tersebut adalah putusan atas Permohonan Praperadilan yang diajukan oleh Hadi Poernomo atas penetapan dirinya sebagai tersangka oleh Komisi Pemberantasan Korupsi . Permohonan tersebut diputus dan dibacakan pada tanggal 26 Mei 2015 oleh Hakim H. Haswandi, SH.,SE.,M.Hum., yang dalam amar putusanya diantaranya menyatakan bahwa penyidikan yang dilakukan oleh KPK sebagai dalam penetapan Hadi Poernomo sebagai tersangka adalah tidak sah dan menyatakan bahwa penyidikan yang dilakukan oleh Komisi Pemberantasan

\footnotetext{
${ }^{20}$ Cst Kansil,op.cit.,hlm. 38

${ }^{21}$ Putusan Pengadilan Negeri Jakarta Selatan dalam Praperadilan Komjen.pol. Budi Gunawan V. Komisi Pemberantasan Korupsi,Nomor 04/Pid.Prap/2015/PN.JKT.Sel.,hlm 41.
} 
Korupsi tidak mempunyai kekuatan hukum mengikat, serta memerintahkan Komisi Pemberantasan Korupsi untuk menghentikan penyidikan. ${ }^{22}$

Ketentuan Pasal 83 ayat (1) KUHAP menentukan bahwa terhadap putusan praperadilan tidak dapat dimintakan banding, kecuali putusan praperadilan menetapkan tidak sahnya penghentian penyidikan atau penuntutan. Oleh karena itu putusan Praperadilan diatas yang menyatakan bahwa penyidikan yang dilakukan oleh penyidik adalah tidak sah dan tidak mempunyai kekuatan hukum mengikat serta memerintahkan kepada termohon untuk menghentikan penyidikan tidak dapat dimintakan banding pada Pengadilan Tinggi.

Disini terdapat pertentangan antara putusan praperadilan yang memerintahkan Korupsi Pemberantasan Korupsi untuk menghentikan penyidikan dengan Pasal 40 Undang-Undang Nomor 30 tahun 2002 tentang Komisi Pemberantasan Korupsi yang melarang KPK menerbitkan surat penghentian penyidikan.

Ditinjau dari asas res judicata proveritate habetur, asas ini adalah asas hukum umum atau asas hukum yang berhubungan dengan seluruh bidang hukum. ${ }^{23}$ Asas tersebut mengandung pengertian bahwa putusan pengadilan harus dianggap benar sebelum pengadilan yang lebih tinggi memutus lain, termasuk apabila ada pertentangan antara putusan pengadilan dengan Undang-Undang, maka yang dianggap benar adalah putusan hakim. Berdasarkan asas ini dapat dikatakan bahwa Komisi Pemberantasan Korupsi harus menghentikan penyidikan atas tersangka korupsi Hadi Poernomo walaupun Pasal 40 Undang-Undang Nomor 30 Tahun 2002 tentang Komisi Pemberantasan Korupsi Melarang nya.

22 Pengadilan negeri jakarta selatan dalam Praperadilan hadi purnomo V. Komisi Pemberantasan Korupsi Nomor 36/Pid.Prap/2015/PN.JKT.Sel.,hlm 20

${ }^{23}$ Bambang Sutiyoso, Metode Penemuan Hukum. cetakan kedua. Yogyakarta: UII Press, 2015, hlm 27. 
Berdasarkan uraian diatas dapat disimpulkan bahwa pemuatan norma penetapan tersangka oleh Mahkamah Konstitusi dalam Putusan Mahkamah Konstitusi Nomor 21/PUU-XII/2014 juga berimplikasi terhadap penerapan Pasal 40 Undang-Undang Nomor 30 tahun 2002 tentang Komisi Pemberantasan Korupsi, walaupun Undang-Undang Komisi Pemberantasan Korupsi merupakan pengkhususan dari KUHAP. Putusan Mahkamah Konstitusi Nomor 21/PUU-XII/2014 berimplikasi sebagai Yurisprudensi. Putusan Mahkamah Konstitusi Nomor 21/PUU-XII/2014 terkait pengujian Pasal 77 huruf a KUHAP dapat diikuti atau dijadikan dasar oleh hakim lain dalam memutus perkara yang berkaitan dengan penetapan tersangka, penggeledahan dan penyitaan, dengan kata lain putusan Mahkamah Konstitusi tersebut dapat menjadi yurisprudensi.

Karena putusan Mahkamah Konstitusi langsung memperoleh kekuatan hukum tetap sejak dibacakan dan mengikat untuk umum. Menurut Bagir Manan, sistem Peradilan Indonesia tidak menganut asas precedent. ${ }^{24} \mathrm{Hal}$ tersebut berarti hakim-hakim di Indonesia dalam membuat putusan bebas untuk mengikuti atau tidak mengikuti putusan-putusan hakim terdahulu, atau menganut asas bebas. Walaupun demikian, dalam praktiknya banyak hakim di Indonesia yang menuruti atau mengikuti putusan hakim sebelumnya, terutama putusan hakim atau pengadilan yang kedudukannya lebih tinggi, diantaranya adalah Putusan Mahkamah Konstitusi Nomor 21/PUU-XII/2014.

Terkait jenis yurisprudensi, Putusan Mahkamah Konstitusi Nomor 21/PUU-XII/2014 terkait pengujian Pasal 77 huruf (a) KUHAP dapat digolongkan sebagai yurisprudensi tidak tetap, karena Mahkamah Konstitusi dalam putusan tersebut tidak mempertimbangkan putusan Mahkamah Konstitusi sebelumnya, jadi Mahkamah Konstitusi murni melakukan penemuan hukum sendiri. Tetapi setelah putusan tersebut dibacakan, banyak

\footnotetext{
${ }^{24}$ Bagir Manan, Teori dan Politik Konstitusi, Jakarta: Rajawali pers, 2000, hlm. 57
} 
putusan pengadilan yang pertimbangannya didasarkan atas putusan Mahkamah Konstitusi tersebut, maka putusan Mahkamah Konstitusi tersebut tergolong sebagai yurisprudensi tetap, karena diikuti oleh hakim lain dalam memutus perkara praperadilan, sebagaimana dicontohkan pada implikasi poin pertama diatas.

Implikasi terhadap proses peradilan pidana. Dimasukkannya penetapan tersangka sebagai objek praperadilan oleh Mahkamah Konstitusi dapat menimbulkan proses acara pidana berjalan lama, karena dalam KUHAP tidak diatur batasan tentang berapa kali praperadilan itu dapat diajukan. Mahkamah Konstitusi dalam pertimbangannya mengatakan bahwa "dimasukkannya penetapan tersangka sebagai objek praperadilan tidak kemudian diartikan bahwa tersangka tersebut tidak belrsalah dan menggugurkan adanya tindak pidana, sehingga dapat dilakukan penyidikan kembali sesuai dengan kaidah hukum yang berlaku secara ideal dan benar".

Pertimbangan Mahkamah Konstitusi tersebut ditindak lanjuti oleh Mahkamah Agung dengan mengeluarkan Peraturan Mahkamah Agung Nomor 4 Tahun 2016 tentang Larangan Peninjauan Kembali Putusan Praperadilan. Pasal 2 ayat (3) peraturan tersebut menyatakan kan bahwa; "Putusan Praperadilan yang mengabulkan permohonan tentang tidak sahnya penetapan tersangka tidak menggugurkan kewenangan penyidik untuk menetapkan yang bersangkutan sebagai tersangka lagi setelah memenuhi dua alat bukti yang sah, berbeda dengan alat bukti sebelumnya yang berkaitan dengan materi perkara."

Permasalahan yang timbul adalah apabila permohonan atas penetapan tersangka itu dikabulkan oleh praperadilan, dan penyidik kembali melakukan penyidikan dan kembali menetapkan orang tersebut sebagai tersangka. Atas tindakan penyidik dalam penetapannya kembali sebagai tersangka, tersangka tersebut dapat kembali mengajukan praperadilan, dan dapat terus berulang 
apabila permohonan praperadilan atas penetapannnya sebagai tersangka terus dikabulkan oleh praperadilan.

5.5. Analisis Putusan Mahkamah Konstitusi No 21/PUU-XII/2014 Mengenai Pengujian Pasal 77 huruf a KUHAP terkait dengan fungsi Mahkamah Konstitusi sebagai Positif Legislator di tinjau dari Undang-Undang Nomor 24 Tahun 2003 J.O Undang-Undang Nomor 11 tahun 2011 tentang Mahkamah Konstitusi

Putusan Mahkamah Konstitusi yang bersifat positif legislator merupakan bagian dari praktik judicial activism yang dilakukan oleh hakim dengan maksut agar tujuan hukum dapat tercapai. ${ }^{25}$

apabila terjadi sebuah kekosongan hukum seorang hakim harus mampu melakukan sebuah terobosan hukum (rule breaking) agar putusan memberikan keadilan ,kemanfaatandan sebuah kepastian hukum bagi masyarakat. Berdasarkan alasan keadilan hakim dapat mengesampingkan peraturan perundang-undangan apabila dalam penerapan nya dikhawatirkan ketidak adilan .

Putusan Mahkamah Konstitusi yang bersifat positif legislator memang tidak berdasar hukum atau bertentangan dengan hukum ,tetapi bila di tinjau dari perspektif tujuan hukum .putusan Mahkamah Konstitusi yang bersifat positif legislator dapat dibenarkan bila putusan tersebut dapat memenuhi tujuan hukum .karena hukum itu dibuat dengan tujuan agar dapat meciptakan keadilan dan kepatian hukum bagi masyarakat. Terdapat batasan bagi Mahkamah Konstitusi dalam memfungsikan diri nya sebagai positif legislator yaitu putusan tersebut harus dibuat untuk melindungi hak Konstitusional warga negara ,dibuat untuk mengisi kekosongan hukum dan dibuat dalam kondisi mendesak. ${ }^{26}$

\footnotetext{
${ }^{25}$ Martitah, Mahkamah Konstitusi dari Negative Legislature ke Positive legislature, Jakarta : Konstitusi Press,2000, hlm 167.

${ }^{26}$ Ibid.,hlm 168.
} 
Pertama pertimbangan Mahkamah Konstitusi dalam membuat norma baru dalam putusan Nomor 21/PUU-XII/2014 ditinjau dari hak konstitusional warga negara fungsi Mahkamah Konstitusi sebagai pengawal konstitusi atau sebagai pelindung konstitusi dapat di artikan Mahkamah Konstitusi sebagai pelindung hak asasi manuasia terutama sejak di inkorporasi nya hak-hak asasi manusia dalam Undang-Undang Dasar 1945 Fungsi perlindungan terhadap hak asasi konstitusional tersebut harus tercermin dalam setiap putusan Mahkamah Konstitusi.

Perlindungan hak konstitusional dalam Undang-Undang Dasar 1945 mecangkup perlindungan terhadap hak -hak atau kepetingan warga negara secara keseluruhan hal itu tecermin dalam pembukaan Undang-Undang Dasar 1945 yang menyatakan "untuk melindungi segenap bangsa indonesia dan untuk memajuakan kesejahteraan umum". Pancasila sebagai dasar negara mengandung pemikiran bahwa manusia di ciptakan oleh Tuhan Yang Maha Esa dengan menyandang dua aspek yaitu aspek idnividualitas dan aspek sosialitas, oleh karena itu kebebasan seseorang dibatasi oleh hak asasi orang lain. Ini berarti setiap orang berkewajiban untuk menghormati hak asasi orang lain.

Perlindungan terhadap hak asasi manusia harus dilaksanakan secara adil. konsep keadilan dalam Pancasila dirumuskan dalam sila ke 2 yang Menyatan "kemanusiaan yang adil dan beradab", makna adil dalam sila ke 2 tersebut dijabarkan dalam ketetapan MPR NO XVIII/MPR/1998 dengan arti gotong royong keseimbangan antara hak dan kewajiban memiliki fungsi sosial hak milik dan hak hidup bersama ${ }^{27}$

Berdasarkan uraian diatas diketahui bahwa perlindungan terhadap hakhak kemanusiaan harus dilaksanakan secara adil dalam artian harus ada keseimbangan antara perlindungan terhadap hak atau kepentingan individu

${ }^{27}$ Bahder Johan Nasution, Negara Hukum Dan Hak Asasi Manusia,Bandung : C.V Mandar Maju, 2012, hlm. 187 
dengan perlindungan terhadap hak dan kepentingan publik .jangan sampai hak dan kewajiban kepentingan individu melanggar hak dan kewajiban kepentingan publik. Sebagaimana diatur dalam pasal 28J ayat 1 dan 2 Undang-Undang Dasar 1945.

Oleh karena itu sebagai pelindung hak konstitusioanal warga negara Mahkamah Konstitusi juga harus mempertimbangkan hak atau kepentingan publik disamping hak atau kepentingan individu (dalam hal ini pemohon) dalam setiap putusan yang di buat,sehingga dapat dikatakan bahwa Mahkamah Konstitusi telah membuat putusan secara adil.

Berkaitan dengan Putusan Mahkamah Konstitusi dalam menguji pasal 77 huruf (a) KUHAP bertentangan dengan Undang-Undang Dasar 1945 sepanjang tidak dimaknai termasuk penetapaan tersangka, pengeledahan dan penyitaan. Pertimbangan Mahakamah Konstitusi dalam memasukan ke absahan penetapan tersangka sebagai objek Praperadilan pada intinya adalah supaya perlakuan terhadap seseorang dalam proses pidana memperhatikan tersangka sebagai manusia yang mempunyai harkat

dan martabat serta kedudukan yang sama dihadapan hukum. Masalah yang timbul adalah dengan dimasukan nya penetapan status tersangka dalam objek Praperadilan ,apakah Mahkamah Konstitusi telah berlaku adil dengan memperhatikan hak konstitusional pemohon dan hak konstitusional masyarakat secara seimbang atau terhadap hak pemohon saja.

Menurut hakim konstitusi I Gede Palguna ada dua kepentingan yang hendak dilindungi secara seimbang melalui Praperadilan yaitu kepentingan individu dalam hal ini tersangka atau terdakwa dan kepentingan publik atau masyarakat ,dimasukan nya penetapan tersangka dalam objek praperadilan berarti membenarkan ketidak seimbangan perlindungan kepentingan individu dan kepentingan publik . sebab bagi seseorang yang ditetapkan sebgaia tersangka tersedia dua jalan untuk mepersoalkan penetapan tersebut yaitu memohon penghentian penyidikan atau praperadilan, sementara itu jika 
masyarakat atau pihak ketiga hendak mempersoakan tindakan penyidik yang menghentikan penyidikan hanya tersedia satu jalan yaitu Praperdilan.

Berdasarkan pendapat di atas dapat dimengerti bahwa dengan memasukan penetapan tersangka dalam objek Praperadilan, berarti Mahkamah Konstitusi telah memberikan perlindungan hak konstitusional warga Negara secara tidak seimbang karena Mahkamah Konstitusi lebih mementingkan kepentingan tersangka dibandingkan kepentingan publik. Selain itu tidak dimasukan nya penetapan tersangka sebagai objek praperadilan bukan berarti KUHAP tidak memposisikan tersangka atau terdakwa sebagai subjek manusia yang mempunyai harkat ,martabat dan kedudukan yang sama dihadapan hukum, karena di dalam kuhap terdapat asas praduga tidak bersalah yang menggagap setiap orang yang disangka ,ditangkap ditahan di tuntut dan atau dihadapkan dimuka sidang pengadilan wajib di anggap tidak bersalah sampai adanya keputusan hukum tetap ${ }^{28}$

Tujuan utama pelembagaan praperadilan dalam kuhap pada prinsip nya adalah untuk melakukan pengawasan horizontal atas tindakan upaya paksa yang dikenakan terhadap tersangka selama ia berada dalam pemeriksaan penyidikan atau penuntutan ,agar benar-benar tindakan itu tidak bertentangan dengan ketentuan hukum dan Undang-Undang. ${ }^{29}$

Bila di cermati keberadaan Pranata Praperadilan untuk mengawasi halhal yang bersifat prosedural. tindakan upaya paksa yang dikenakan terhadap tersangka pada tingkat penyidikan atau penuntutan telah dijalankan sesuai prosedur yang benar atau tidak, bukan hal-hal yang berkaitan dengan materi perkara. Penetapan tersangka adalah ujung dari proses penyidikan sebagai mana diatur dalam Pasal 1 ayat 2 KUHAP yang menyatakan "Penyidikan adalah serangkaian tindakan penyidik dalam hal dan menurut cara yang di

28 C.S.T Kansil, Pengantar Ilmu Hukum Dan Tata Hukum Indonesia, Jakarta : Balai Pustaka,1989, hlm. 348

${ }_{29}$ Andi hamzah, Hukum Acara Pidana Indonesia Edisi Kedua, Jakarta : Sinar Grafika,2008, hlm. 71 
atur dalam undang-undang ini untuk mencari serta mengumpulkan bukti yang dengan bukti itu membuat terang tindak pidana yang terjadi dan guna menemukan tersangkanya".

Pasal tersebut menunjukan bahwa penetapan tersangka bukanlah upaya paksa ,tetapi ujung dari tindakan atau upaya paksa yang dilakukan oleh penyidik. Sedangkan yang dapat dijadikan objek dalam Praperadilan hanyalah upaya paksa yaitu upaya paksa itu tidak dilakukan sesuai prosedur yang benar. Oleh karena itu dalam pertimbangan nya Mahkamah Konstitusi menyatakan bahwa dalam hal penetapan tersangka yang dapat diajukan Praperadilan adalah mengenai proses yang dilakukan oleh penyidik dalam menetapan seseorang sebagai tersangka.

Berkaitan dengan pertimbangan Mahkamah Konstitusi yang menyatakan bahwa sistem yang di anut oleh KUHAP adalah akusator . menurut Andi Hamzah sistem yang dianut oleh KUHAP adalah akusator terbatas. ${ }^{30}$

Pembatasan terhadap objek praperadilan dalam Pasal 77 KUHAP merupakan bagian dari pembatasan hak-hak tersangka dalam Kuhap berdasarkan sistem akuisator terbatas pembatasan terhadap hak-hak tersangka tersebut di sisi yang lain merupakan bentuk perlindungan kuhap terhadap hak-hak atau kepentingan masyarakat pada umumnya. oleh karena itu tidak dimasukan nya penentapan tersangka dalam Pasal 77 huruf (a) KUHAP adalah wujud perlindungan kuhap terhadap hak-hak atau kepentingan masyarakat. Dimasukannya penentapan tersangka sebagai objek praperadilan dalam Pasal 77 huruf (a) kuhap oleh Mahkamah Konstitusi, berarti Mahkamah Konstitusi telah mengesampingkan hak-hak masyarakat, hal ini juga sejalan dengan pendapat hakim konstitusi I gede dewa pulgana diatas bahwa dimasukannya penetapan tersangka kedalam objek

\footnotetext{
${ }^{30}$ Ibid.,hlm 72.
} 
praperadilan membuat perlindungan kepentingan individu dan kepentingan publik menjadi tidak seimbang.

Berdasarkan uraian diatas dapat disimpulkan bahwa dengan dimasukan nya penetapan tersangka ke dalam objek praperadilan berarti Mahkamah Konstitusi telah memberikan perlindungan hak konstitusional warga negara secara tidak seimbang, karena Mahkamah Konstitusi lebih mementingkan hak konstitusional individu (tersangka) . hal ini terlihat dari pertimbangan Mahkamah Konstitusi yang hanya didasarkan pada perlindungan hak konstitusionalitas pemohon individu saja .

Kedua pertimbangan Mahkamah Konstitusi dalam membuat norma baru dalam putusan Mahkamah Konstitusi Nomor 21/PUU-XII/2014 ditinjau dari kekosongan hukum dan kondisi yang mendesak . sebagaimana telah diuraiakan sebelumnya bahwa dalam membuat putusan yang bersifat positif legislator ,hakim harus memperimbangkan bahwa akan terjadi kekosongan hukum yang dapat menimbulkan permasalahan dalam masyarakat bila tidak di buat putusan yang bersifat positif legislator dan masalah yang diputus dalam kondisi yang mendesak. Kekosongan hukum adalah kondisi dimana peraturan atas suatu peristiwa konkrit itu belum ada, sehingga terdapat kekosongan hukum (rechts vacuum).

Definisi tentang kondisi mendesak, dapat ditinjau dari istilah "kegentingan yang memaksa" sebagaimana terdapat dalam Pasal 22 ayat (1) Undang-Undang Dasar 1945) yang menyatakan "Dalam hal ihwal keadaan yang memaksa, Presiden berhak menetapkan peraturan pemerintah sebagai pengganti undang-undang." Hal tersebut juga diatur dalam Pasal 1 angka 4 UU Nomor 12 Tahun 2011 tentang Pembentukan Peraturan Perundangundangan, yang menyatakan "Peraturan Pemerintah Pengganti UndangUndang adalah Peraturan Perundang-undangan yang ditetapkan oleh Presiden dalam hal ihwal kegentingan yang memaksa. 
Kedua Pasal tersebut mensyaratkan bahwa dibuatnya peraturan pemerintah pengganti Undang-Undang (selanjutnya disebut Perpu) adalah adanya hal ihwal kegentingan yang memaksa. Berdasarkan Putusan Mahkamah Konstitusi Nomor 138/PUU-VII/2009 ada tiga syarat sebagai parameter adanya "kegentingan yang memaksa" bagi Presiden untuk menetapkan PERPU yaitu, adanya keadaan yaitu kebutuhan mendesak untuk menyelesaikan masalah hukum secara cepat berdasarkan Undang-Undang, Undang-Undang yang dibutuhkan tersebut belum ada sehingga terjadi kekosongan hukum, atau ada Undang-Undang tetapi tidak memadai, dan kekosongan hukum tersebut tidak dapat diatasi dengan cara membuat Undang-Undang secara prosedur biasa karena akan memerlukan waktu yang cukup lama sedangkan keadaan yang mendesak tersebut perlu kepastian untuk diselesaikan.

Berdasarkan parameter adanya kegentingan yang memaksa dalam putusan Mahkamah Konstitusi diatas, dapat dicermati bahwa keadaan mendesak dapat diartikan dalam tiga hal, yaitu: mendesak karena adanya masalah hukum yang harus segera diselesaikan, mendesak karena belum ada aturan untuk mengatasi masalah hukum tersebut, sehingga terjadi kekosongan hukum, serta mendesak karena waktu untuk membuat aturan dalam bentuk Undang-Undang memerlukan waktu yang lama, sedangkan masalah hukum yang timbul harus segera diselesaikan.

Ditinjau dari kondisi mendesak berupa kekosongan hukum, apakah benar terdapat kekosongan hukum yang dapat dijadikan dasar oleh tersangka atau terdakwa untuk menuntut haknya atas tindakan penetapan tersangka, penggeledahan, dan penyitaan yang dilakukan tidak sesuai prosedur, sehingga Mahkamah Konstitusi memasukkan penetapan tersangka, penggeledahan, dan penyitaan sebagai objek Praperadilan.

Berkaitan dengan penetapan tersangka, pertimbangan Mahkamah Konstitusi dalam memasukkan penetapan tersangka kedalam objek 
Praperadilan adalah semata-mata untuk melindungi seseorang dari tindakan sewenang-wenang penyidik yang kemungkinan besar dapat terjadi ketika seseorang ditetapkan sebagai tersangka, padahal dalam prosesnya ternyata ada kekeliruan.

Berdasarkan pertimbangan Mahkamah Konstitusi tersebut dapat dipahami bahwa wewenang Praperadilan dalam mengadili permohonan penetapan tersangka adalah sebatas mengenai proses yang dilakukan oleh penyidik dalam menetapkan seseorang sebagai tersangka dan proses tersebut berupa upaya paksa, karena yang dapat dijadikan objek praperadilan adalah sebatas mengenai tindakan upaya paksa yang tidak dilakukan sesuai dengan prosedur yang benar. Selanjutnya, apakah terdapat kekosongan hukum dalam KUHAP mengenai perlindungan terhadap hak tersangka atas tindakan upaya paksa yang tidak dilakukan sesuai prosedur yang benar oleh penyidik dalam menetapkan dirinya sebagai tersangka.

Berdasarkan Pasal 26 Peraturan Kapolri Nomor 14 Tahun 2012 tentang Manajemen Penyidikan Tindak Pidana, yang dimaksud dengan upaya paksa adalah meliputi; pemanggilan, penangkapan, penahanan, penggeledahan, penyitaan, dan pemeriksaan surat. Beberapa tindakan upaya paksa tersebut apabila tidak dilakukan sesuai dengan prosedur yang benar, KUHAP telah memberikan Hak terhadap tersangka untuk mengajukan Praperadilan sebagaimana diatur dalam Pasal 77 sendiri dan Pasal 95 sampai pasal 97 KUHAP, yang mana seseorang yang ditetapkan sebagai tersangka tanpa melalui proses dan prosedur yang benar dapat mengajukan ganti kerugian dan rehabilitasi kepada Praperadilan.

Berkaitan dengan penggeledahan dan penyitaan. Penggeledahan dan penyitaan merupakan bagian dari tindakan upaya paksa yang dilakukan oleh penyidik. Dalam KUHAP telah terdapat aturan tentang penggeledahan dan penyitaan. Mengenai penggeledahan, telah diatur dalam Pasal 1 angka 17- 
19, dan Pasal 32 sampai Pasal 37 KUHAP. Mengenai penyitaan telah diatur dalam Pasal 1 angka 16 dan Pasal 38 sampai Pasal 46 KUHAP.

Baik penggeledahan maupun penyitaan, apabila tidak dilaksanakan sesuai prosedur yang benar, maka tersangka atau terdakwa berhak mengajukan ganti kerugian pada Praperadilan, sebagaimana diatur dalam Pasal 95 ayat (1) KUHAP, yang menyatakan :

"Tersangka, terdakwa, atau terpidana berhak menuntut ganti kerugian karena ditangkap, ditahan, dituntut, dan diadili, atau dikenakan tindakan lain, tanpa alasan yang berdasarkan undang-undang atau kekeliruan yang berdasarkan undang-undang atau kekeliruan mengenai orangnya atau hukum yang diterapkan".

Penjelasan Pasal 95 ayat (1) KUHAP menjelaskan bahwa "yang dimaksud kerugian karena tindakan lain ialah kerugian yang ditimbulkan oleh pemasukan rumah, penggeledahan dan penyitaan yang tidak sah menurut hukum".

Tuntutan atas ganti kerugian tersebut dapat diajukan pada praperadilan, ${ }^{31}$ sebagaimana diatur dalam Pasal 77 huruf b KUHAP yang menyatakan :

"Pengadilan negeri berwenang unuk memeriksa dan mengadili sesuai dengan ketentuan dalam undang-undang ini tentang: ganti kerugian dan atau rehabilitasi bagi seseorang yang perkara pidananya dihentikan pada tingkat penyidikan atau penuntutan".

Berdasarkan uraian tersebut, dapat diketahui bahwa tersangka berhak mengajukan ganti kerugian kepada praperadilan atas tindakan upaya paksa baik berupa penangkapan, penahanan, penggeledahan, penyitaan dan pemeriksaan surat yang tidak dilakukan sesuai dengan prosedur yang benar, sebagaimana telah diatur dalam Pasal 77 huruf b KUHAP. Akan tetapi dikabulkannya gugatan ganti kerugian atas tindakan upaya paksa yang tidak

${ }^{31}$ M.Karjadi dan R.soesilo, Kitab Undang-Undang Hukum Acara Pidana Dengan Penjelasan Resmi Dan Komentar,Bogor, 1997, hlm. 88 
dilakukan sesuai prosedur yang benar tersebut tidak serta merta menggugurkan status seseorang sebagai tersangka.

karena dalam hal ini Pasal 82 ayat (3) KUHAP yang mengatur tentang isi putusan praperadilan, tidak mengatur tentang batal tidaknya status tersangka bila proses dalam menetapkan seseorang sebagai tersangka tidak dilakukan sesuai prosedur yang benar, jadi sejauh tentang penetapan tersangka dalam hal ini terdapat kekosongan hukum.

Selanjutnya, mengenai pertimbangan Mahkamah Konstitusi dalam membuat norma baru terhadap Pasal 77 huruf a KUHAP ditinjau dari kondisi waktu yang mendesak. Pertimbangan Mahkamah Konstitusi, sebagaimana telah diuraikan dalam hasil penelitian, tidak didapati pertimbangan Mahkamah Konstitusi yang menyatakan bahwa pengujian Pasal 77 huruf a KUHAP dilakukan dalam kondisi yang mendesak, yaitu kondisi yang mengharuskan Mahkamah Konstitusi menambah norma baru dalam amar putusannya.

Mantan ketua Mahkamah Konstitusi Prof.Dr.Mahfud M.D menyatakan Mahkamah Konstitusi dalam melaksanakan kewenangan nya terutama dalam melakukan peng ujian Undang-Undang terhadap Undang-Undang Dasar 1945 Mahkamah Konstitusi hanya boleh menyatakan sebuah UndangUndang bertentangan atau tidak dengan Undang-Undang Dasar 1945 dan tidak boleh masuk keranah legislatif (ikut mengatur) dengan cara apapun. Pada umum nya pembatasan tugas yang demikian dikaitkan dengan pengertian bahwa Dewan Perwakilan Rakyat dan Pemerintah adalah Positif Legislator sedangkan Mahkamah Konstitusi adalah Negatif Legislator(penghapus atau pembatal norma). ${ }^{32}$

Landasan yuridis yang melarang Mahkamah Konstitusi membuat norma baru terhadap norma yang sudah di batalkan telah di atur ke dalam hlm. 280

${ }^{32}$ Mahfud M.D, Konstitusi dan Hukum Dalam Kontroversi Isu,Jakarta, Rajawali Pers, 2010, 
Undang-Undang Nomor 8 Tahun 2011 tentang Mahkamah Konstitusi pasal 57 ayat 2 (a) yang menyatakan putusan Mahkamah Konstitusi tidak memuat tentang :

5.5.1. Amar selain yang di maksut pada ayat (1) dan (2)

5.5.2. Perintah kepada pembuat Undang-undang dan

5.5.3. Rumusan norma sebagai pengganti norma dari undang-undang yang di nyatakan bertentangan dengan UUD 1945.

Oleh karena itu, menurut penulis Mahkamah Konstitusi kurang tepat bila memfungsikan dirinya sebagai positive legislator dalam menguji Pasal 77 huruf a KUHAP.

\section{Kesimpulan}

Berdasarkan hasil penelitian dan pembahasan diatas dapat disimpulkan bahwa: Putusan Nomor 21/PUU-XII/2014 mengenai pengujian Pasal 77 huruf (a) KUHAP menimbulkan akibat hukum antara lain :

6.1. Semakin banyak nya Gugatan Praperadilan yang bertujuan untuk melepaskan diri dari penetapan tersangka oleh penyidik terutama dalam perkara Korupsi.

6.2. Berakibat permasalahan hukum baru yaitu perang antara Praperadilan melawan surat Perintah Penyidikan.karena sampai saat ini belum ada aturan yang membatasi pengajuan permohonan Praperadilan dan penerbitan Sprindik baru atas putusan Praperadilan yang telah di putuskan hakim.

6.3. Putusan Mahkamah Konstitusi No 21/PUU-XII/2014 Tentang penambahan penetapan tersangka menjadi objek Praperadilan berimplikasi pada pasal 40 UU No 30 tahun 2002 tentang Komisi Pemberantasan Korupsi. Karena dalam pasal tersebut menyatakan"Komisi Pemberantasan Korupsi tidak berwenang mengeluarkan surat penghentian penyidikan dan penuntutan dalam perkara tindak pidana Korupsi”. 
Ditinjau dari aspek Yuridis Putusan Mahkamah Konstitusi Nomor 21/PUUXII/2014 cacat Hukum karena Bertentangan dengan pasal 57 Undang-Undang Nomor 8 Tahun 2011 tentang Mahkamah Konstitusi. Yang menyatakan bahwa Mahkamah Konstitusi dilarang membuat norma baru atas Norma yang telah di batalkan.

Berdasarkan tinjauan tersebut, dapat disimpulkan bahwa dalam Putusan Nomor 21/PUU-XII/2014 Mahkaham Konstitusi kurang tepat bila memfungsikan dirinya sebagai positive legislator, sehingga dapat dikatakan bahwa Mahkamah Konstitusi dalam hal ini telah mengintervensi ranah legislatif sebagai positive legislator. 


\section{DAFTAR PUSTAKA}

\section{Literatur Ilmiah}

Ashiddiqie, Jimly, Pokok-pokok Hukum Tata Negara Indonesia Pasca Reformasi, Jakarta: PT.Bhuana Ilmu Populer, 2007.

Cst Kansil,. Pengantar Ilmu Hukum dan Tata Hukum Indonesia, cetakan ke-7, Jakarta : Balai Pustaka, 1986.

Hamzah, Andi, Hukum Acara Pidana Indonesia, edisi kedua, Jakarta : Sinar Grafika,2008.

Khayatudin, Pengantar Mengenal Hukum Indonesia, Kediri: Uniska Prees, 2010.

Mahfud M.D, Konstitusi dan Hukum Dalam Kontroversi Isu, Jakarta : Rajawali Pers, 2010.

Manan, Bagir, Teori dan Politik Konstitusi, Jakarta: Rajawali pers, 2000.

Martitah, Mahkamah Konstitusi dari Negative Legislature ke Positive legislature, Jakarta : Konstitusi Press,2000.

Nasution, Bahder Johan, Negara Hukum dan Hak Asasi Manusia, Bandung : C.V Mandar Maju, 2012.

Sekretariat Jenderal MPR RI,2011, Panduan Permasyarakatan Undang-undang Dasar Negara Republik Indonesia tahun 1945 dan ketetapan Majelis Permusyarakatan Rakyat Republik Indonesia, Jakarta.

Sumadi, Ahmad Fadlil, "Hukum Acara Mahkamah Konstitusi Teori Dan Praktik"Jurnal Konstitusi,Edisi No. 8 Vol. 6 (2011).

Sutiyoso, Bambang, Metode Penemuan Hukum, cetakan kedua, Yogyakarta: UII Press, 2015.

\section{Peraturan Perundang-Undangan}

Undang-Undang Dasar Negara Republik Indonesia Tahun 1945.

UU Nomor 8 Tahun 2010 tentang Pencegahan dan Pemberantasan Tindak Pidana Pencucian Uang

M.Karjadi dan R.soesilo, Kitab Undang-Undang Hukum Acara Pidana Dengan Penjelasan Resmi Dan Komentar,Bogor, 1997.

Putusan Pengadilan Negeri Jakarta Selatan dalam Praperadilan Komjen.pol. Budi Gunawan V. Komisi Pemberantasan Korupsi,Nomor 04/Pid.Prap/2015/PN.JKT.Sel.

\section{Media Online}

Irwanto, Deny, Gugatan Praperadilan Suroso Atmo Martoyo Ditolak PN Jaksel,http://news.metrotvnews.com, diakses Tanggal 22 Mei 2017.

Rakhamulloh, PN Jaksel Tolak Gugatan Praperadilan Jero Wacik,http://nasional.sindonews.com/read/994766/13,Diakses Pada Tanggal 23 mei 2017 
Agustin, Hasry, PN Jaksel Tolak Praperadilan Nur Alam,http//www.hukumonline.com/berita/baca/21 diakses pada tanggal 30 mei 2017.

Status Tersangka Dahlan Islan Gugur,http/www.bbc.com/indonesia.diakses pada tanggal 22 mei 2017

Kejari surabaya," Praperadilan Laa Nyalla sampai berapa babak?" dalam http://www.Kejari sby.co.id /Artikel-Praperadilan-La nyalla-sampaiberapa-babak Diakses pada 27 januari 2017.

http//nasional.harianterbit.com/nasional/2016/05/16/61"Jaksa Dilarang Ajukan PK,MK Dinilai Lindungi Koruptor,” di akses pada 30 mei 2017

http//detik.news/berita/3212914"Jaksa Dilarang PK,ini Mereduksi Pencari Keadilan," Diakses pada 30 mei 2017

http//Surabaya.tribunnews.com/2016/04/13"Ini Sikap La Nyalla Terkait Keluarnya Sprindik Baru Kajati Jatim,"diakses pada 30 mei 2017

http//Beritacenter.com/news/52759"Gugatan Praperadilan Kadin di Kabulkan Hakim Surabaya,"diakses pada 30 mei 2017. 